\title{
JOHN JAY (1745-1779): DE ABOGADO COLONIAL A DIRIGENTE MODERADO DE LA REVOLUCIÓN AMERICANA.
}

\section{JOHN JAY (1745-1779): FROM COLONIAL LAWYER TO MODERATE LEADER OF AMERICAN REVOLUTION.}

\author{
Jorge Pérez Alonso \\ Abogado \\ Investigador del Seminario Martínez Marina de Historia Constitucional \\ (Universidad de Oviedo)
}

\begin{abstract}
SUMARIO: I.- APROXIMACIÓN BIBLIOGRÁFICA A LA FIGURA DE JOHN JAY. II.ENTORNO FAMILIAR Y SOCIOCULTURAL (1745-1764). III.- EJERCICIO DE LA ABOGACÍA (1764-1774). IV.- SALTO A LA VIDA PÚBLICA (1774-1776): LÍDER MODERADO DE LA RESISTENCIA COLONIAL. 4.1.- El Comité de Nueva York y la Letter to the Committee of Correspondance. 4.2.- Primer Congreso Continental. La Address to the People of Great Britain. 4.3.- Segundo Congreso Continental. La Letter from Congress to the opressed inhabitants of Canada y la Olive Branch Petition. V.- ARTICULANDO JURIDICAMENTE EL ESTADO DE NUEVA YORK (1776-1779). REDACTOR DE LA CONSTITUCIÓN DE 1777 Y PRIMER CHIEF JUSTICE. 5.1.- Nacimiento del estado de Nueva York. La Address of the Convention of the Representatives of the State of New York to their Constituents. 5.2.- La Constitución de Nueva York, aprobada el 20 de abril de 1777. 5.3.- Chief Justice de Nueva York y renuncia a ser candidato a Gobernador. Nueva elección como delegado al Congreso Continental. VI.- PRESIDENTE DEL CONGRESO CONTINENTAL (1778-1779). 6.1.- Elección como Presidente del Congreso Continental. 6.2.- Sistema institucional de los Estados Unidos en 1779. 6.3.Labor de Jay como Presidente del Congreso. 6.4.- Nombramiento como ministro plenipotenciario de los Estados Unidos en España. VII.- EPÍLOGO. CIERRE DE UNA FUCTÍFERA ETAPA
\end{abstract}

Resumen: John Jay es quizá, cuando menos en nuestro país, un padre fundador olvidado. Aun siendo popular fundamentalmente por ser quien negoció el Tratado de Paz de 1794 entre los Estados Unidos y Gran Bretaña, gran parte su vida pública es totalmente desconocida. Jay fue un abogado colonial de éxito, delegado al Primer y Segundo Congreso Continental, redactor de la primera Constitución del estado de Nueva York, primer embajador de los Estados Unidos en España, integrante de la Comisión negociadora del Tratado de Paz de París, 
Secretario de Asuntos Exteriores en el régimen de los Artículos de la Confederación, primer Presidente del Tribunal Supremo de los Estados Unidos y segundo Gobernador del Estado de Nueva York. El presente artículo aborda los primeros veinticinco años de su vida, comenzando por su entorno social y familiar, continuando con su carrera como abogado en el Nueva York colonial y su papel en la primera fase de la revolución americana, especialmente en su estado natal.

Abstract: John Jay is perhaps a forgotten founder, at least in our country. He is mostly known for being the diplomat who negotiate in 1794 the Treaty of Peace between Unites States and Great Britain, most of his public life is entirely unknown to many people. Jay was a very sucessful colonial attorney, delegate to the First and Second Continental Congress, drafter of the first Constitution of New York, first United States ambassador to Spain, member of the Commission who negotiate the Treaty of Paris, Secretary of Foreign Affairs under the Articles of Confederation, first Chief Justice of the United States and second Governor of New York. This article deals with the first twenty-five years of his life, beginning with his social and familiar background, continuing with his career as attorney in colonial New York and his rol in the first stage of American Revolution, specially in his native state.

Palabras clave: Estados Unidos, Padres fundadores, Siglo XVIII, John Jay

Key Words: United States, Founding fathers, Eighteenth century, John Jay

"Civil and religious liberty is a blessing which I sincerely wish to all mankind; and I hope it will ever be the policy of these States so to extend and secure it to all their Citizens, as that none may have reason to complain of partiality and oppresion" (John Jay a Anthony Benezet, 5 de marzo de 1779)

\section{APROXIMACIÓN BIBLIOGRÁFICA A LA FIGURA DE JOHN JAY.}

Es curioso que, pese a ser uno de los padres fundadores, John Jay sea en gran medida una personalidad muy poco conocida en España, a pesar de que durante un trienio ostentó nada menos que el cargo de representante de las colonias rebeldes en la corte del rey Carlos III, siendo, por tanto, el primer embajador de los Estados Unidos en nuestro país. Buena prueba de ese olvido o desvío en España hacia la figura de Jay lo tenemos en la recentísima edición que se ha hecho en lengua castellana del clásico El federalista y donde en su magnífico estudio preliminar, Ramón Maiz efectua una amplia exposición del pensamiento político no sólo de los coautores James Madison y Alexander Hamilton, sino del de Thomas Jefferson, que para nada intervino en su redacción; sin embargo, omite significativamente toda referencia a John Jay, quien sólo es mencionado de pasada un par de ocasiones en las dos páginas iniciales $^{1}$. La situación no era, hasta hace relativamente poco tiempo, muy

1 El Federalista, Akal, 2015. Es cierto que la contribución última de Jay a dicha obra es minima si se la compara con las aportaciones de James Madison y Alexander Hamilton, pero no 
distinta en los propios Estados Unidos. Aun cuando a modo de reconocimiento público en su estado natal, el nombre de John Jay está vinculado desde el año 1966 a una institución educativa (John Jay College of Criminal Justice) su figura histórica se encontraba sumida en un velo de oscuridad, permaneciendo difuminada en la memoria colectiva, más por sus tareas como como diplomático encargado de negociar el tratado de paz entre los Estados Unidos y Gran Bretaña suscrito en 1794 y como gobernador de Nueva York que como líder independentista y como juez, pese a haber sido durante un bienio el máximo responsible de la judicatura en su estado natal y durante un lustro el primer chief justice de los Estados Unidos.

En el eclipse histórico de la figura de Jay, paradójicamente tuvieron no poco que ver los encargados de perpetuar su legado, pues durante casi un siglo la imagen de John Jay vino a constituirse en una especie de patrimonio familiar no accesible a terceros, con la particularidad de que incluso un no desdeñable sector de la propia familia estaba disconforme con la imagen pública que se estaba transmitiendo de su ancestro. Durante un siglo, concretamente el periodo que transcurre entre 1833 y 1935, las aproximaciones biográficas a la figura de Jay estuvieron monopolizadas por miembros de su familia.

En 1833, tan sólo cuatro años después del óbito de John Jay, su hijo William publicó una biografía en dos volúmenes, Life of John Jay ${ }^{2}$, obra que aún hoy sigue teniendo sumo interés no tanto por su calidad literaria, sino porque gracias a ella podemos hacernos una idea de la imagen "oficial" de Jay que perduró hasta el primer tercio del siglo XX. Ello es así porque la segunda biografia que sobre el personaje aparece a en los años finales del siglo XIX, la publicada por David Pellow con el título John Jay: his life and times ${ }^{3}$, no sólo fue elaborada por otro descendiente de Jay, sino que en muchos aspectos se apoya en la anterior biografia escrita por William Jay así como en alguna que otra aportación de John Jay II, nieto del biografiado. Esta especie de monopolio se rompe en 1935 al publicarse el primer ensayo histórico redactado extramuros del entorno familiar, el debido a Frank Monaghan y titulado John Jay: Defender of liberty $^{4}$. En el prefacio al libro, el autor reconoce que ha tenido libre acceso al archivo de Jay y que, por vez primera, es posible que "a non-family biographer to present a new, complete and perhaps definitive portrait of one of the most sifnificant and interesting figures of eighteenth century America", ofreciendo una critica al

es menos cierto que Thomas Jefferson no contribuyó para nada a la misma y sin embargo Maíz analiza con bastante amplitud el pensamiento de este último autor, sin que en las casi ochenta páginas de la, insistimos, magnífica introducción se facilite al lector ni tan siquiera de forma esquemática las ideas de Jay sobre el particular. Maíz ni tan siquiera menciona que Jay fue, en solitario, el autor del opúsculo Address to the People of the State of New York, publicado en abril de 1788 y obra que, según los estudiosos, contribuyó a que Nueva York ratificase el texto constitucional en mucha mayor medida que todos los artículos de El Federalista.

2 J. \& J. Harper, Nueva York, 1833. La biografia stricto sensu se limitaba al primer volumen, mientras que en el segundo se recogían parte de los escritos y cartas de Jay.

3 Houghton, Mifflin and Company, Nueva York, 1890, publicada dentro de la serie American Statesmen. Esta biografía se reeditó en 1997 y goza de una edición mucho más reciente en Palala Press, 2016.

${ }^{4}$ Bobbs Merrill Company, Nueva York, 1935 
panorama en que desde el punto de vista histórico se encontraba la imagen de Jay, de la que culpa casi exclusivamente a las anteriores biografias ${ }^{5}$. Monaghan intenta superar esa visión austera, fría y lejana de Jay presentándolo como un hombre de carne y hueso, con sus filias y fobias, con sus pasiones y, sobre todo, sin desdeñar su vertiente pública, acercar al lector a la vida personal y familiar de Jay. Pese que su autor esperaba que dicha biografia fuese "quizá definitiva", siete décadas más tarde apareció la que hasta el momento es la última aproximación a tan interesante figura histórica, la escrita por Walter Starr con el título John Jay: founding father, que vio la luz en el año 20066. A finales del año 2016 Carol Brier publicó un ensayo titulado Mr. Jay of Bedford: John Jay, the retirement years 1801-18297, que como su propio título indica, se centra básicamente en los últimos veintiocho años de Jay, cuando éste ya se había retirado de la vida pública para disfrutar de la vida familiar

Algo parecido ocurrió con su fondo documental. La edición canónica del mismo era hasta mediados del siglo XX la debida a Henry P. Johnston, publicada en cuatro volúmenes a finales del siglo $\mathrm{XIX}^{8}$. Pero dicha recopilación, con ser

5 "William Jay not only lacked literary ability, but was haunted by a stange sense of propriety which deformed his labors. The portrait that he wished to present to posterity was that of the statesman, not the man. He rigorously supressed harmless and interesting details, picturing his father as having lived in an atmosphere which no mortal counld long have breathed. The picture which he gave was that of Frazee's marble bust: a petrified Roman in a toga. In this pious work a great American, who was frequently witty and sometimes ribald, became the coldpersonification of austerest virtue. Jay was virtuous and dignified, yet the juice of life ran strong withing him. William's Elder brother, Peter Augustut, strongly critizied the treatment of his father [...] It is ironical that William Jay did as much to obscure as to elucidate the fame of his father [...] George Pellew, a nephew of Jay's grandson. Among serious hándicaps were his limitations of space [...] his failure to study adequately the private papers of Jay, and his too-ready acceptance of the attitude of William Jay, upon whuse work Pellow largely based his own. His biography was inspired, and some of it dictated, by John Jay 2nd"; Frank MONAGHAN, John Jay: Defender of liberty, op. cit., p. VII-VIII. De la misma opinión se mostraba Milton L KLEIN, quien en la página 365 del volumen 21-4 (octubre de 1977) de la American Journal of Legal History, glosando la publicación de una edición renovada del archivo de Jay debida a Richard B. Morris, suscribía punto por punto las afirmaciones de Monaghan, al indicar al respecto que: "A life and letters, published by is son in 1833, elevated Jay to the level of a parangon of oficial virtue -grave, stately and dull. Even other members of the family complained of the stiffness of the subject who emerged from these insipid volumes. A biography published in 1890 by another descendant, Daniel [sic] Pellew, suffered the same defect, since it drew largely upon William Jay's coldly formal portrait."

6 Bloomsbury Academic, 2006

7 Carol BRIER, Mr. Jay of Bedford, John Jay, the retirement years, 1801-1829, Heritage Books, 2016. En el primer capítulo, la autora ofrece en treinta páginas un valioso resumen de la vida pública de Jay. Indicar que pese a que el estudio se centra en sus años finales, a lo largo del mismo no deja de hacer referencia a cartas y acontecimientos que tuvieron lugar años antes, en pleno apogeo de la vida pública del biografiado. El objetivo último del libro radica en desterrar la imagen de que John Jay era un hombre roto y abatido tras la muerte de su esposa (acaecida en mayo de 1802), sino que aun cuando en su pacífico retiro y rodeado de su familia, continuaba muy al tanto de los acontecimientos politicos, sobre los cuales se pronunciaba en sus cartas particulares.

8 Correspondence and public papers of John Jay, G.P. Putnam's sons, Nueva York, 1890-1893. Para Milton L KLEIN esta recopilación "was a bowdlerized version and contained Little of the personal side of a man who could be a gallant husband, a voncical friend and a warm and doting father"; American Journal of Legal History, vol. $21 \mathrm{n}^{\circ} 4$ [octubre 1977] p. 365. En adelante, la cita 
evidentemente de interés para estudiar la vertiente pública y el pensamiento político de Jay, no era en modo alguno completa al tener importantes lagunas, sobre todo en lo que se refería los asuntos estrictamente familiares. A mediados de la década de los cincuenta del siglo XX, Richard B. Morris emprendió la tarea de publicar una versión mucho más rigurosa y crítica de las cartas y documentos obrantes en el archivo de Jay, pero su fallecimiento en el año 1989 dejó inconcluso el proyecto, habiendo visto la luz hasta ese momento únicamente dos volúmenes publicados respectivamente en 1975 y 1980 que abarcaban el periodo vital del personaje hasta el año 17849 . Ya en la primera década del siglo XXI, Elisabeth M. Nuxoll retomó la labor iniciada a mediados del siglo XX por Morris, de tal forma que, partiendo del trabajo previo realizado por dicho autor, ofrece una nueva edición crítica y actualizada en siete volumenes del fondo documental de Jay, de la que han aparecido ya cuatro de ellos, el último en el año 201510. A modo de complemento de la meritada publicación, gran parte de los documentos de John Jay han sido digitalizados y son accesibles a través de internet ${ }^{11}$.

\section{ENTORNO FAMILIAR Y SOCIOCULTURAL (1745-1764).}

Para acercarnos a la figura de John Jay, forzosamente hemos de partir del entorno geográfico, social, cultural y familiar en el que nació y creció, pues el mismo tuvo una notable incidencia en su formación personal e intelectual.

de los Correspondence and public papers la haremos por sus iniciales, CPP, seguida por la indicación del tomo en números romanos y en arábigos la página concreta del tomo.

9 John Jay, the making of a Revolutionary: unpublished papers, 1745-1780, Harper and Row, Nueva York, 1975, y John Jay, the winning of the peace: unpublished papers, 1780-1784, HarperCollins, Nueva York, 1980. En las páginas 1-10 de la introducción publicada en el primero de los volúmenes, Morris ofrecía una vivida narración de los avatares sufridos por las cartas y documentos del archivo Jay. En realidad estos volúmenes, más que una recopilación propiamente dicha (como la de Johnston) es una biografia documentada, pues divide la vida de Jay en etapas, a cada una de las cuales antepone un breve estudio preliminar para, a continuación, ilustrarla con los documentos relativos a esa época, abundantemente anotados. El propio Richard Morris califica la edición de "documented biography" en las páginas introductorias.

10 Selected papers of John Jay, Virginia University Press, 2010-2015; en adelante se citarán como SPJJ, seguido, al igual que en el caso de los CPP, del número romano correspondiente al tomo y en arábigo la página concreta del volumen. El primero de los tomos abarca desde el nacimiento de Jay en 1745 hasta su marcha a España como embajador de los Estados Unidos en 1779; el segundo ocupa todo el periodo en que Jay permaneció en nuestro país (1779-1782), el tercero desde su llegada a París en 1783 para concluir el tratado de paz con Inglaterra hasta su regreso a los Estados Unidos en 1784; y el cuarto (y cuando se escriben estas líneas último de ellos que ha visto la luz) comprende todo el periodo en el que Jay ostentó el cargo de Secretario de Asuntos Exteriores de los Estados Unidos bajo los Artículos de la Confederación, es decir, de 1784 hasta julio de 1788. Siempre que sea posible, utilizaremos esta edición.

11 https://dlc.library.columbia.edu/jay. Conviene indicar al respecto que dicho fondo tiene una enorme ventaja, cual es que permite combinar varios filtros de búsqueda (fundamentalmente por fechas y nombre del destinatario o emisor de las cartas), e incluso tiene en la página inicial unas pestañas donde se ofrece un resumen de aspectos relevantes de la vida de Jay (en relación al texto constitucional, a la esclavitud, al tratado de paz de 1794 con Gran Bretaña) incorporando el enlace directo a la versión digitalizada de los principales documentos relativos a la etapa en cuestión. 
Su familia, de emigrantes franceses, había fijado su residencia en Nueva York tres generaciones atrás, y desde mucho antes se había vinculado profesionalmente a la actividad mercantil. Nota característica de los Jay era también una presencia fundamental de la religión en su vida familiar, adscribiéndose desde el punto de vista confesional al cristinanismo de raiz protestante, pues eran descendientes de hugonotes franceses.

En sus años de retiro, y poco antes de su muerte, el propio Jay emprendió, a petición de su familia y para uso exclusivamente privado, una investigación genealógica en busca de los orígenes de sus ancestros. El manuscrito original de dicho ensayo genealógico se ha perdido, aunque tenemos conocimiento del mismo porque William Jay la reprodujo en el capitulo inicial de la biografia de su padre $^{12}$. Este buceo en la genealogía familiar era algo a lo que Jay otorgaba suma importancia, más que nada para evitar que la leyenda aflorase en el campo que la historia y la investigación habían dejado yermo, hasta el punto de que acabaran tomándose por ciertos hechos que no lo eran. Así lo manifestaba en los siguientes términos:

\begin{abstract}
"How fleeting, how forgetful, how frail is tradition. There are families in this State who are ignorant even of the names of the first of their ancestors who came to this countrythey kow not whence, or why, or how they came. Between those days and the period of our revolucion, the field for biography has become barren-little has been written, and of that little much has been lost by the destruction of papers during the war. The time, however, is approaching when this barren field will be cultivated by genius and by pride; and, under the auspices of obscurity (even friendly to fiction), become fertile in fables. My faith in the generality of historical relations of every kind has been gradually declinin for these thirty years. On various occasions I have seen accounts of events and affairs which I knew to be incorrect..."
\end{abstract}

Pese a lo expuesto en el párrafo anterior, John Jay únicamente logró remontarse hasta su bisabuelo Pierre, vecino de la región francesa de Poicteau, aunque la rama familiar de la que procedian se trasladó a La Rochelle. Cuando Luis XIV promulga en 1685 el Edicto de Fontainebleau, que dejaba sin efecto el Edicto de Nantes de 1598 y reinstauraba una política de persecución de los cristianos reformistas, Pierre Jay, próspero mercader vinculado al protestantismo, hubo de huir del país, logrando escapar a Inglaterra tras una breve estancia en una carcel francesa, después de varias peripecias dignas de una novela de Rafael Sabatini. Pierre Jay tenía tres hijos y una hija. Mientras que su hija contraería matrimonio con Stephen Peloquin, un próspero comerciante de Bristol, el segundo de sus hijos, Augusto, que había sido educado en Inglaterra, emigró a las colonias americanas. Al principio se estableció en Carolina del Sur, pero al no lograr aclimatarse, decidió emprender rumbo a Filadelfia para acabar asentándose definitivamente en Nueva York, donde, al igual que su progenitor antes que él, se dedicó al comercio. Es precisamente en dicha ciudad donde contrae matrimonio en 1697 con Ana María Bayard, descendiente de un profesor de teologia que hubo de exiliarse de Francia por los mismos motivos que la

12 William JAY, Life of John Jay, op. cit, vol. I, p.1-9. Jay lamentaba que su dedicación a la vida pública le hubiese impedido abordar con anterioridad tal investigación, a la que atrbuía gran importancia. Véase, al respecto, el primer capítulo del libro de Frank Monaghan, John Jay: Defender of liberty, op. cit., p. 1-22. 
familia Jay. Tras ver su existencia iluminada con tres hijas, el 3 de noviembre de 1704 nace su primer hijo varón, al que llaman Peter en recuerdo de su abuelo paterno.

Peter Jay, tras ser enviado a Inglaterra para su educación, regresa a su Nueva York natal y en 1728 contrae matrimonio con Mary Van Cortland. De ese matrimonio nace el 12 de diciembre de 1745 su octavo hijo, John ${ }^{13}$, quien recibe ese nombre en recuerdo de su tío John Chambers, uno de los jueces de la Supreme Court of Judicature.

John Jay crece en un cálido ambiente familiar aun cuando según el último biógrafo de Jay, el padre "possessed strong masculine sense, was a shrewd observer and admirable judge of men; resolute, persevering and prudent; an affectionate father, a kind master, but governing all under his control with mild but absolute sway." Uno de los aspectos fundamentales en la vida de la familia Jay era la fuerte presencia de la religión, que les ayudó a sobrellevar desdichas familiares, como la enfermedad que privó de la vista a dos de los hermanos de John. La fe religiosa de los padres, de honda raíz protestante y fuertemente anticatólica, caló hasta tal punto en sus miembros que, como indica David Monaghan, "in this deeply pious atmosphere the maturing yough was molded; nor did three quarters of a century of growing skepticism and scientific thought effect the smallest change in these early opinions." 14 Y es que, en efecto, cuando ya en el otoño de su vida Jay se vió aquejado por sucesivas desgracias familiares, su sólida fe religiosa y la creencia en que la existencia terrena era el preámbulo de una vida mejor fue lo que le ayudó a sobrellevar sus últimos años ${ }^{15}$.

Johnny, como era conocido entonces familiarmente, pronto demóstró, a ojos paternos, una buena disposición para los estudios. Según indicaba Peter Jay, en carta escrita el 3 de julio de 1752 a su hijo James: "[Johnny] is of a very grave disposition and takes to learning exceeding well. He has lately gone through the five declensions etc. with much ease and is now in the verbs. He will be soon fit to go to a Grammar school"; un año más tarde informaba a su pariente John Peloquin que: "he seems to be endowed with a very good capacity, is very reserved, and quite of his brother James's disposition for books."16 Tras ser instruido por su madre en las primeras letras, en 1753 es enviado al colegio que el reverendo Peter Stouppe regentaba en New Rochelle, donde permaneció tres años, regresando después a su casa natal en Rye. Cuatro años más tarde, en 1760, es enviado al King's College, entonces regido por el reverendo Samuel Johnson. En dicha

13 Peter Jay elaboró un documento que contenía una relación cronológica de todos los eventos familiares que afectaban al matrimonio Jay-Van Cortland y su desdendencia. Una transcripción del mismo puede encontrarse en Richard B. MORRIS, John Jay, the making of a revolutionary (1745-1780), op. cit., p. 31-32. Según consta en dicho documento, "December 1st/ 12th N.S 1745. On Sunday at ten OClock at night is born my sixth Son John Jay and baptized on Fryday the 6th/ 17 following by the Revd. Mr William Vesey, having Messr Cornelius Van Horn, John Chambers and Mrs Ann Chambers for his sureties."

14 David MONAGHAN; John Jay, defender of liberty, op. cit., p. 25.

15 Véase Carol BRIER, Mr Jay of Bedford, op. cit., p. 79-85.

16 Carta escrita el 24 de octubre de 1753 por Peter Jay a David y John Peloquin, en Richard B MORRIS, John Jay, the making of a revolutionary, op. cit., p. 36-37 
institución conocerá a muchos que a lo largo de toda su vida fueron grandes amigos, y destacará académicamente ${ }^{17}$, recibiendo cuatro años más tarde, el 15 de mayo de 1764, el título de Bachelor of Arts. Es en estos años cuando, al parecer, se adentra en la lectura de las Vidas paralelas de Plutarco, cuya visión idealizada de las virtudes del republicanismo clásico tendría honda influencia en el carácter y el pensamiento de Jay ${ }^{18}$. Como dato curioso, indicar que se conserva una copia de los estatutos del colegio transcritos de forma manuscrita por Jay, quien firmó los mismos como "Johannes".

De esta etapa formativa inicial, conviene retener dos circunstancias apuntadas por Walter Starr. La primera, el carácter conservador, cuando no abiertamente autoritario, de muchos líderes revolucionarios educados en el King's College ${ }^{19}$. La segunda, e intimamente ligada a la anterior, el hondo impacto que los tumultos y desórdenes callejeros ligados a la fase inicial del conflicto revolucionario que acabaría desencadenándose abruptamente, dejaron en el ánimo de Jay, en cuyo pensamiento se inoculó un fuerte recelo hacia el elemento democrático, si bien en este punto no difería en nada de la inmensa mayoria de los founding fathers ${ }^{20}$.

Por tanto, a la hora de aproximarse al carácter y al pensamiento de Jay ha de incidirse en varios hechos determinantes. Primero, su nacimiento en Nueva York, es decir, en la populosa capital de la colonia del mismo nombre. Segundo, el ambiente familiar, en lo económico vinculado por tradición al comercio, y en lo religioso inclinado desde hacía generaciones a la rama protestante del

17 Refiriéndose al ya adolescente John, el director de la institución, reverendo Samuel Johnson, escribía a Peter Jay en carta fechada el 24 de septiembre de 1762: "I cant but express to you my satisfaction in the prociciency \& conduct of your son. I have good reason to hope (as I pray God) he may be an honour \& confort both to you and me as well as a blessing to his country”, en SPJJ, I, 12.

18 Frank MONAGHAN, John Jay, defender of liberty, op. cit., p. 28.

19 "The King's alumni who were revolutionario liders, including John Jay, Alexander Hamilton, Governeur Morris and Robert Livingston, were not leaders of street riots, but opponents of popular violence. It is hard to say whether students learned respect for authority at King's College, or thether the college only admitted students who respected authority, but in any case the men who emerged from the early college were conservative, even authoritarian". Walter STARR, John Jay, founding father, op. cit. p. 25 (dado que esta obra se ha consultado en formato ebook, la numeración puede variar en el caso del formato en papel. En todo caso, las referencias a esta obra se hacen teniendo en cuenta que se consultó la misma en un Ipad Air de 9,7 pulgadas)

20 "Jay also learned in the 1760s various lessons about democracy. He saw what were deemed the proper procedures for protesting an Act of Parliament, in the form of the Stamp Act Congress and the Assembly's respectful petition. But he also saw at first hand more "popular'forms of protest, such as the Stamp Act riots, and asmuch as he deplored violence, he must have noticed its power. It was not the polite petitions of the Stamp Act Congress, but rather the mob threatening his life, which forced Governor Colden to abandone any hope of distributing the stamps. Jay would, throughout his life, have an uneasy relationship with popular democracy". Walter STARR, John Jay, founding father, op. cit., p. 37. En este sentido, Jay no se diferenciaba del resto de lideres independentistas norteamericanos, porque como indicara acertadamente Bruce Ackerman "The men of 1787 were very proud of being revolutionary, but talk of democracy made them nervous [...] If common folk were given real power, they might abandon the elites and cede politial control to petty politicians who would fail to impose the stringent self-discipline needed to place the public interest over factional desire", The failure of the founding fathers: Jefferson, Marshall and the rise of presidential democracy, Harvard University Press, 2005, p. 16 y 18. 
cristianismo, con una fuerte presencia del mismo en la vida cotidiana de la familia. Tercero, su formación académica en una institución donde el conservadurismo tenía una fuerte presencia. Y, por último, la experiencia vital en estos años formativos que le inculca un fuerte recelo hacia el elemento popular.

\title{
III. EJERCICIO DE LA ABOGACÍA (1764-1774): FORMACIÓN Y APERTURA DE DESPACHO PROPIO ${ }^{21}$.
}

Cuando menos desde un año antes de finalizar su estancia en el King's College, John Jay había decidido orientar su futuro hacia el mundo jurídico, pues el 23 de agosto de 1763 su padre le escribía una carta aceptando tal decisión ${ }^{22}$, algo que no le debió causar mucha sorpresa pues un año antes, cuando su hijo estaba a punto de finalizar los estudios, había escrito a uno de sus parientes que, "is indued with very good natural parts and is bent upon a learned Profession, I believe it will be the Law"23.

A mediados del siglo XVIII, el ejercicio de la abogacía profesional no estaba en modo alguno vinculado a la posesión de un título universitario superior. El único modo de entrar a formar parte de la comunidad letrada consistía en incorporarse a un despacho como pasante, aprender los rudimentos de la abogacía de forma práctica $\mathrm{y}$, tras un periodo más o menos amplio, independizarse y abrir un bufete propio. Quizá dicha forma de adquirir la capacitación profesional pueda extrañar sobremanera al jurista del siglo XXI, pero lo cierto es que el sistema funcionaba a la perfección y a finales del siglo XVIII las colonias americanas posian un grupo notable de abogados de primera categoria, empezando por John Adams y terminando por John Marshall. A este respecto William Hubbs Rehquist (excelente jurista que acabó siendo juez del Tribunal Supremo de los Estados Unidos y culminó su carrera como chief justice), al referirse al juez Samuel Freeman Miller reflexionaba de esta forma sobre la ineficacia de una excesiva formación teórica en detrimento de la práctica, afirmación que el redactor de estas líneas, abogado de profesión, suscribe de la primera a la última letra:

\begin{abstract}
"Miller's great gift, a gift no so fully vouchsafed to some of his more learned colleagues, was that of common sense. It may seem odd in a profession that now requires four years of college and three years of law school even to qualify to attempt to pass a bar examination and gain admision, that common sense should be rated so highly as an attribute of a judge. But it has been well said that legal education sharpens a person's
\end{abstract}

21 Sobre la etapa de Jay como abogado, ver Herbert A. Johnson John Jay: Lawyer in a time of transition, University of Pennsylvania Law Review, vol 124 n 5 p. 1260-1292, en cuyas lineas iniciales se indica que: "his life at the bar is a valuable point of departure for studying the legal profession in the last decade of the colonial period and for considering the role of the lawyer in colonial society and in the coming of the American Revolution." Johnson amplió ulteriormente este trabajo convirtiéndolo en libro, con el título John Jay, colonial lawyer, Beard Books, 1988.

22 "Your observation on ye Study of Ye Law, I believe, is very just, and as its your inclination to be of that Profession, I hope you'll closely attend to it with a firm resolution that no difficulties in prosecuting that Study shall discourage you from applying very close to it, and if posible, from taking a delight in it'. Carta de Peter Jay a John Jay, 23 de agosto de 1763, obrante en Richard M MORRIS, John Jay: The making of a revolutionary, op. cit., vol. p. 48-49.

23 Carta de Peter Jay a David Peloquin, fechada el 16 de mayo de 1762, SPJJ, I, 10-11. 
mind by narrowing it, and in the battle of opposing counsel, each of whom seeks to deduce an opposite conclusion from the same premise, a good judge must at every moment be willing to call a halt and say to the advocate: Your argument is perfectly logical, but the result for which you contend seems to me absurd."24

Con todo, a mediados de la década de los sesenta del siglo XVIII no corrían buenos tiempos para quienes decidieron orientarse profesionalmente hacia la abogacía. En octubre de 1756, la comunidad letrada ejerciente en Nueva York (que apenas llegaba entonces a los cuarenta abogados), con el fin de restringir la competencia, acordó no incorporar a los despachos profesionales a ningún pasante durante los próximos catorce años, lo que suponía bloquear el acceso de nuevos aspirantes hasta el año 1770. Cerrada, pues, la puerta en Nueva York, Peter Jay buscó que su hijo se formase profesionalmente como abogado en Inglaterra, contactando al efecto con sus familiares en dicha nación a fin de encontrar un despacho jurídico en Bristol o Londres donde John pudiese incorporarse, si bien Peter Jay se inclinaba expresamente por Bristol, dado que así su hijo tendria el apoyo de los Peloquin, parientes que residian en dicha localidad inglesa ${ }^{25}$. Finalmente, no hubo necesidad de llegar a tales extremos, pues el día 5 de enero de 1764 la abogacía neoyorkina dejaba sin efecto el acuerdo tomado en 1756 y, con ello, posibilitaron que John Jay se incorporase a un despacho en la ciudad 26 .

Eliminado, pues, el obstáculo principal, Peter Jay logró un acuerdo económico con el abogado Benjamín Kissam para que éste admitiese a Jay como pasante 27 . Según las condiciones pactadas, John se incorporaría una vez finalizados sus estudios en el King's College, y permanecería durante un lustro junto a Kissam, abonándole doscientos dólares por esos cinco años de aprendizaje. Por cierto, es curioso que la admisión de John Jay en el despacho de Kissam fue algo irregular dado que, según el acuerdo adoptado por la abogacía neoyorkina el 5 de enero de 1764, cada abogado únicamente podría admitir un pasante, y a la hora de admitir a Jay en el despacho de Kissam ya había uno, Lindley Murray, que había comenzado su aprendizaje el año anterior ${ }^{28}$.

Tal y como estaba previsto, John se incorpora en 1764 al bufete de Benjamin Kissam. La vida de un pasante no era, ciertamente, algo comparable a lo que hoy en día puede ser la estancia en un despacho profesional ${ }^{29}$, y pese a ello, según

24 William H. REHNQUIST, The Supreme Court, Alfred A. Knopff, 2001, p.99.

25 Cartas de Peter Jay a James Jay (15 de febrero y 14 de abril de 1763) y a David Peloquin (14 de abril de 1763), en SPJJ, I, 15 y 22-24.

26 Herbert A. JOHNSON, John Jay, a lawyer in time a of transition, 1764-1775, op. cit., p. 12601261. Según William JAY "whether because it was found imposible to enforce it, or because its authors shrank from the odium it excited, is now unknown"; William JAY, Life of John Jay, op. cit., p. 14 .

27 En relación al acuerdo entablado entre Peter Jay y Benjamin Kissam, véase la carta dirigida a aquél a su hijo John el día 16 de enero de 1764 así como la que Peter Jay envía a David Pelloquin el 15 de mayo de 1774, en SPJJ, I, 30-32.

28 SPJJ, I, 29, nota introductoria.

29 "The life of a law clerck in the eighteenth century was not easy. Every document had to be written out by hand, and the hand was usually that of one of the clerks. Research was difficult because there wer relatively few books to work from, and these books were written in almost 
todos los biografos, Jay y Kissam lograron entablar una relación de abierta y sincera amistad. Durante el primer año, dieciséis de los diecisiete escritos presentados por Kissam ante la Supreme Court of Judicature de Nueva York estaban redactados por Jay. Estos años de pasantía en el despacho coinciden temporalmente con la crisis desatada por la aprobación de la Stamp Act, que lógicamente afectó a la abogacía colonial dado que los escritos procesales debían redactarse en papel timbrado. Para evitar un enfrentamiento directo con la metrópoli, se suspendieron los procedimientos en el orden jurisdiccional civil y durante el tiempo de vigencia de la Stamp Act, únicamente se celebraron vistas penales, dado que este tipo de casos estaban subjetivamente exentos del impuesto $^{30}$. Jay se así directamente implicado en la resistencia pasiva a un tributo considerado injusto.

Es en estos años de aprendizaje jurídico cuando tiene lugar un episodio curioso en su vida. Estando aún de pasante, entra a formar parte del Debating $C l u b$, una institución auspiciada por eminentes jóvenes neoyorkinos e ideada como plataforma de debate y promoción de ideas politicas, éticas y filosóficas. En el mes de enero de 1768 se planteó como asunto a debatir si en el seno de una monarquía absoluta es preferible la sucesión hereditaria o electiva. La opción de Jay es clara, la monarquia electiva, puesto que "If the son of a king was entitled to rule, Jay said, his father's interest would secure him the election. If, on the other hand, the election was contested between members of the nobility, the elective process would warantee a contest between men of the greatest merit, for the nobility have an equal interest with the people in the government of the state. Finally, if a man was elected King in a constitutional way from among candidates of equal merit, the people will submit"31

El acuerdo inicial con Kissam, como hemos indicado anteriormente, estipulaba que Jay permanecería en el despacho cinco años, periodo establecido según las normas de la abogacía colonial. No obstante, un acuerdo adoptado en 1767 por el la Supreme Court of Judicature de Nueva York redujo ese periodo de formación práctica a tres años. Kissam y Jay acordaron que éste reduciría su estancia un año respecto a los cinco inicialmente previstos. El día 28 de octubre de 1768 el gobernador sir Henry Moore expedía a Jay su licencia professional para el ejercicio de la abogacia, cuyo texto indicaba que: "being well assured of the ability and learning of John Jay, Gentleman, I have thought fit to appoint him an Attorney at Law, hereby authorizing him to appear in all his Majesty's Courts of Record within the Province of New York, and there to practice as an Attorney at Law,

impenetrable legal language. Th esenios lawyers were often busy ora ay, so that they had limited time to guide their clerks". Walter STARR, John Jay, founding father, op. cit., p. 29; Herbert A. Johnson, habla de los "grueling and tedious writings tasks assigned to all la clerks in the colonial period" y se extiende sobre los mismos precisando que "the colonial law Clerk performed all of the duties which today are assigned to a legal stenographer, as well as the functions of a managing Clerk and a legal researcher", John Jay: Lawyer in a time of transition, 1764-1775, p. 1262. He optado en este caso por traducir la expresión law clerk como pasante, aun siendo consciente de que no éste un término absolutamente exacto.

30 Herbert A. JOHNSON, John Jay: Lawyer in a time of transition, 1764-1775, p. 1267-68.

31 Herbert A. JOHNSON, John Jay: Lawyer in a time of transition, 1764-1775, p. 1269; Walter STARR, John Jay, founding father, op. cit., p. 35-36. 
according to the Laws and Customs of that part of Great Breain called England, and the Law and customsof the said province. And all Judges, Justices and others concerned and hereby required to admit him accordingly." 32

Pese al notable talento jurídico de Jay, parece claro que fueron sus contactos y relaciones familiares asi como su amistad con Benjamín Kissam las que le ayudaron a despegar su carrera profesional ${ }^{33}$. Su mentor jurídico no sólo le desvió algunos de sus asuntos, sino que influyó para que su antiguo pupilo fuese nombrado secretario de la Comision que habia de delimitar las fronteras entre las colonias de Nueva York y Nueva Jersey. Esta experiencia profesional tuvo el efecto, según Frank Monaghan, de inculcar en el joven abogado la eficacia de la "arbitration by a mixed commision as a means of settling disputes between political groups. This idea he later applied to the settlement of international disputes."34

Inicialmente, Jay habia decidido asociarse con su amigo Robert L. Livingston, a quien conoció en su etapa de estudiante en el King's College y con quien durante mucho tiempo mantendría una amistad que iría enfriándose con el tiempo hasta romperse abruptamente en 1789 tras la designación de Jay como primer chief justice. No obstante, la sociedad fue disuelta en 1771, año en el que Jay emprendió una carrera en solitario que le permitió, según uno de los autores que mejor ha estudiado este periodo de su vida: "established a successful and remunerative practive, and by the eve of the Revolution he was among the better known attorneys in the province of New York"35 Como abogado en ejercicio, Jay acudió a todos los órganos jurisdicionales de la colonia: Supreme Court of Judicature, Chancery Court, Mayor Court of New York City asi como los órganos judiciales inferiores sitos en los condados de Queens, Wethester, Dutchess, Ulster y Orange. ${ }^{36}$ Aunque la mayoría de los asuntos que entraban en su despacho eran de índole civil, durante el bienio 1773-1775 se encargó de la defensa de algunos cargos públicos locales en asuntos de naturaleza administrativa, algo que sin duda alguna hizo que su nombre empezara a cotizarse profesionalmente al alza.

Como ultimo dato respecto a estos años en los que Jay ejerció profesionalmente la abogacía, indicar que en el año 1774 efectuo una curiosa propuesta. Dado que en los tribunales del condado servían personas no

$32 \mathrm{El}$ documento, digitalizado y accesible en https://dlc.library.columbia.edu/jay/ldpd:47456, lo reproducia ya fotográficamente Frank Monaghan entre las páginas 46 y 47 de su libro.

33 "More important than talent and industry were his influential connections. He was a member of the aristocracy of the colony. By marriage he was related to some of the first families in New York. His father and granfather had been important merchants; his father was still in financial affairs. Thus he was inmediately placed in touch with the merchants, that groupp of society most frequently in need of a lawyer's skill and cunning.", Frank MONAGHAM, John Jay, defender of liberty, op. cit., p. 40.

${ }^{34}$ Frank MONAGHAN, John Jay, defender of liberty, op. cit., p. 42

35 Herbert A. JOHNSON, John Jay: Lawyer in a time of transition, 1764-1775, p. 1277

36 Sobre los órganos judiciales en la época colonial, además del trabajo citado en la nota anterior pueden consultarse Erwin C. SURRENCY, The Courts in the American Colonies, The American Journal of Legal History, vol. 11 - 3, p. 253-276; Julius GOEBEL jr, History of the Supreme Court of the United States vol I: Antecedents and beginnings to 1801, The Macmillan Company, New York, 1971, p.1-50. 
suficientemente familiarizadas con el ordenamiento jurídico vigente, defendió que fuesen abogados con experiencia quienes fueran designados para desempeñar de forma intinerante (la práctica que recibe el nombre de riding circuit) el puesto de asesores del juez titular ${ }^{37}$, propuesta que no tuvo éxito.

El año 1774 va a ser devisivo tanto a nivel personal como profesional. Lo primero, porque el 28 de abril de 1774 contrae matrimonio con Sarah Livingston (once años más joven que él y descendiente de una de las más ilustres familias de la colonia ${ }^{38}$ ), enlace del que se hace eco la prensa colonial y donde Jay es descrito como "an eminent barrister". Lo segundo, porque el conflicto entre las colonias británicas y la metrópoli mutará el futuro profesional de Jay, haciéndole colgar la toga en beneficio de la política, al verse catapultado inesperadamente a la primera línea de acción pública. Bien es cierto que el cese no fue abrupto, sino gradual, pero la dedicación de Jay a las tareas políticas conllevará que, poco a poco, vaya abandonando el ejercicio de la abogacía. Lo cual, dicho sea de paso, hubiera tenido que hacer de todas formas, pues el conflicto bélico afectó lógicamente a la profesión, dado que la palabra en los estrados hubo de ceder ante la fuerza de las armas, y el estado de Nueva York fue uno de los frentes de batalla. Buena prueba de ello es la carta que Robert Troup dirige a Jay el 30 de octubre de 1775 y en la que le informa del desastroso estado del bufete debido a la situación de guerra existente:

"When I reflect upon the present business of the office, I am filled with the deepest sorrow. Formerly it was extensive, and attended with much profit; now it is confined within very narrow bounds, and of course accompanied with little gain. Mr Strang with his usual care and regularity does whatever is in his power to promote you interest. He acts as council, I perform the office of attorney. We are endavouring to collect the cost which have been long due. I am sorry to say the calamity of the times is a great obstacle to our success." 39

\section{SALTO A LA VIDA PÚBLICA (1774-1776): LÍDER MODERADO DE LA RESISTENCIA COLONIAL.}

\subsection{E1 Comité de Nueva York y la Letter to the Committee of Correspondence.}

Jay se encontraba fuera de Nueva York, tanto por asuntos particulares (tras contraer núpcias, hubo de visitar a algunos miembros de su familia que no residian en la ciudad) como profesionales, cuando el 12 de mayo de 1774 llega a

37 Carta de John Jay a John Vardill, fechada el 23 de mayo de 1774, en SPJJ, I, 87-88.

38 La confianza que en el buen juicio de John tenía su padre queda explícita en la carta que Peter Jay dirige el 31 de enero de 1774 a su futuro consuegro William Livingston: "Tho'we have not the pleasure of knowing the Young Lady, yet the confidence we have in our son's Prudence, satisfies us of the Propriety of his choice." SPJJ, I, 83-84. Al parecer, Jay habia propuesto anteriormente matrimonio sucesivamente a las dos hijas de Peter Lancey (cabeza de otra de las grandes familias neoyorkinas), siendo rechazado por ambas, hecho éste al que algunos atribuyen la inclinación final de Jay por el bando revolucionario, dado que las hijas de Lacey contrajeron matrimonio con personas leales a Inglaterra. Esta interpretación política de un hecho de naturaleza estrictamente personal creo que ha sido acertadamente rechazada por los biógrafos. Frank MONAGHAN, John Jay, defender of liberty, op. cit., p. 46.

39 SPJJ; I, 148. 
la urbe una inquietante noticia: el rey Jorge III había sancionado el 20 de marzo de 1774, la An act to discontinue, in such manner, and for such time as are therein mentioned, the landing and discharging, shipping of goods, wares, and merchandise, at the town, and within the harbour, of Boston, in the province of Massachusetts Bay, in North America, como medida punitiva por los sucesos del Boston tea party. Cuando regresa a la ciudad a finales de mes, se entera que pocos días antes, el 19 de mayo de 1774, había sido designado miembro del Comité ciudadano de Nueva York encargado del estudio de las medidas a adoptar en relación a las leyes aprobadas por el Parlamento británico para castigar la rebelión de Massachussets ${ }^{40}$. Dicho comité, integrado por cincuenta y un miembros, creó en su seno una ponencia de cuatro personas encargada de elaborar un documento de respuesta y apoyo a Massachusets, que finalmente acaba redactando Jay en la que constituirá su primera actuación con cierta relevancia pública. La Letter to the Committee of Correspondence, fechada el 23 de mayo de 1774, es un breve documento cuidadosamente elaborado. Si bien se solidariza abiertamente y muestra su apoyo tanto a la ciudad como a las gentes de Boston, sin embargo no sólo rehúye pronunciarse de forma explícita contra la autoridad británica, sino que tampoco ofrece medida alguna tendente a solucionar el problema, limitándose a solicitar una actuacion conjunta de las colonias $^{41}$. Es cierto que se califican las medidas adoptadas por el Parlamento británico como "alarmantes", que se refiere a la ciudad de Boston como una "ancient and respectable town, which has so long been the seat of freedom" y a Massachussets como una "sister colony, suffering in defence of the rights of America", pero también reconoce que "what ought to be done in a situation so truly critical, while it employs the anxious thoughts of every generous mind, is very hard to be determined" y que "we lament our inability to relieve your anxiety by a decisive opinion." Entre otras cosas, porque la causa "is general, and concerns a whole continent who are equally interested with you and us", razón por la cual el comité neoyorkino aboga porque "a Congress of Deputies from the colonies in general is of the utmost moment; that it oucht to be assembled without delay, and some unanimous resolutions formed in this fatal emergency, not only respecting your deplorable circumstances, but for the security of our common rights." En definitiva, que Nueva York ofrece buenas palabras y un indudable apoyo moral a Massachussets, pero difiere toda respuesta activa desviando tal responsabilidad a un Congreso donde estén representados delegados de todas las colonias, argumentando que la situación no afecta exclusivamente a la ciudad de Boston, sino a todo el continente.

Los miembros más radicales del Comité estimaron insuficiente tal respuesta, y de hecho John Morin Scott se refirió a la actitud de sus integrantes como "pusilánime", lo que motivó que Jay se dirigiese por escrito a aquél y en una carta

40 Frank Monaghan ofrece los siguientes argumentos que avalarían la elección de Jay: "had been nominated by merchants well adquainted with the substantial virtues of his father and gandfather. Some were at that momento debtors of Peter Jay, who held numerous notes and bonds of New Yorkers. They had every reason to asume that the Young lawyer was a safe conservative", John Jay, defender of liberty, op. cit., p. 52

${ }^{41} \mathrm{El}$ documento puede consultarse en $C P P, \mathrm{I}, 13-15$. 
fechada el 22 de junio de 1774 le exige en tono muy respetuoso, pero firme, una satisfacción ${ }^{42}$.

\subsection{E1 Primer Congreso Continental y la Address to the people of Great Britain.}

El ambiente en Nueva York estaba muy dividido. Por un lado se encontraban quienes, como Jay, buscaban un dificil equilibrio entre la defensa de los intereses coloniales y el respeto a la metrópoli, mientras que otro sector más radical presionaba con el objetivo de adoptar soluciones mas drásticas.

Buena prueba de esa división fue la encarnizada lucha que tuvo lugar a la hora de elegir los delegados o representantes para el Congreso Continental. El Comité de cincuenta y un miembros eligió a personas del sector moderado: John Jay, John Alsop, Philip Livingston, Isaac Low y James Duane. No obstante, el Committee of the Mechanics, que integraba a quienes tenian una visión más radical, propuso sustiruir a James Duane y John Alsop por Leonard Lispenar y Alexander McDougall. Tras numerosos conflictos, prevaleció la lista original del Comité de los cincuenta y uno.

La inclusión de Jay parecería sorprendente dada su juventud y falta de experiencia, cuando menos si se compara ésta con la de los otros delegados electos, pero según su Walter Starr, quizá el factor decisivo para explicarse el nombramiento haya sido precisamente esa falta de experiencia política, o más bien el hecho de que "estaba adquiriendo la habilidad politica de hablar como un radical entre los radicales y como un conservador entre los conservadores." 43 De todas formas, es interesante incidir en un aspecto consignado por John Adams en su diario: "Mr. Deane gaves us an account of the delegates of New York. Duane and Jay are lawyers. Livingston, Low and Alsop are merchants. Livingston is very popular. Jay married a Livingston, Peter's daughter, and is supposed to be of his side."44

El lunes día 5 de septiembre de 1774 se inician las sesiones del Congreso Continental, reunido al efecto en el Carpenter's Hall de la ciudad de Filadelfia. Al dia siguiente, martes 6 , tiene lugar un interesante debate ${ }^{45}$ acerca de si la toma

42 En dicha carta, Jay le decía lo siguiente "By the printed hand bill you will percieve, Sir, that I was one of the Committee by whom these resolves were formed, and I am therefore deeply interested in obtaining from you a candid and open declaration of the reasons by which you mean to justify holding us up to publick view in a point of light which men of common honesty and spirit can neither merit nor permit. This is a piece of justice which regard to my carácter yrges me to ask, and which I flatter myself you will have no objections to give." SPJJ I, 92-93.

43 Walter STARR, John Jay, founding father, op. cit., p. 48.

44 John ADAMS, Diary, with passages from an authobiography, incluido en The Works of John Adams, vol II, Charles C. Little and James Brown, 1850, p. 341. Adams indica erróneamente que la mujer de Jay es la hija de Peter Livingston, y aun cuando ambos estaban efectivamente ligados por vínculos familiares, en realidad era hija de William Livingston, que seria gobernador de Nueva Jersey. Es evidente que los vínculos familiares, unidos a su formación jurídica, sirvieron de trampolin a Jay a la hora de ser elegido delegado al Congreso Continental.

45 En el Journal of Continental Congress (Washington Print Office, 1906)no aparecen transcritos los debates, sino las propuestas que se efectúan y si las mismas han sido aprobadas o no. Sin embargo, John Adams, representante o delegado de Massachussets, llevó un diario donde reflejó 
de decisiones ha de efectuarse mediante voto personal o por colonia. Frente a la postura radical de Patrick Henry, defensor a ultranza del voto por cabeza al haberse difuminado la división colonial y no existir a partir de entonces más que "americanos", se alza Jay argumentando que, pese a existir un conflicto evidente, el mismo no ha alcanzado aún el grado suficiente que avale la proclamación de la independencia ("Could I suppose that we came to frame an American constitution, instead of endeavoring to correct the faults in an old one - I can't yet think that all government is at an end. The measure of arbitrary power is not full, and I think it must run over, before we undertake to frame a new constitution"); y a la hora de esgrimir los derechos inherentes a los colonos americanos, Jay invoca no sólo la constitución británica, sino a la ley natural ("It is necessary to recurr to the laws of nature, and the British constitution, to ascertain our rights. The Constitution of Great Britain will not apply to some of the chárter rights") ${ }^{46}$. Conviene no perder de vista respecto a esta última cuestión, es decir, la remisión a la constitución inglesa, un hecho fundamental al que el profesor Horst Dippel ha dedicado un luminoso estudio: la imagen que de la constitución británica tenían los revolucionarios americanos, por cuanto la misma era parcial e interesada, es decir, que los colonos no invocaban "la" constitución inglesa, sino "su" particular visión de la misma ${ }^{47}$.

Finalmente, se impone que la votación no se haría por delegados, sino por colonias, donde cada una de éstas tendría un único voto, acordándose igualmente que las sesiones tendrian lugar a puerta cerrada, imponiendo a los delegados "under the strongest obligations of honour, to keep proceedings secret, untill the majority shall direct them to be made public"48.

En estas primeras sesiones Jay adopta una posición que mantendrá a lo largo de todo el procedimiento revolucionario norteamericano: considera injustificadas las medidas adoptadas por el Parlamento inglés, pero hasta el último momento aboga por reconducir la situación y persuadir a la metrópoli para que las dejara sin efecto, restableciendo asi los lazos de unión y la armonía entre Gran Gretaña y sus colonias. En este punto, es altamente reveladora una misiva que el día 22 de septiembre de 1774 dirige a John Vardill, persona leal a los ingleses, donde Jay, aún manteniendo las reservas que el secreto de las

las intervenciones de los delegados. En adelante, las citas del Journal se harán con las siglas JCC $\mathrm{y}$, al igual que en el caso de los SPJJ, el tomo en número romano y la página en numeración arábiga.

46 John ADAMS, Diary, with passages from an authobiography, vol II, op. cit., p. 368-370. En este sentido, como indica Walter STARR "Jay Agreed with John Adams of Massachussets and others that it was necessary to 'recurr to the law of the nature', as well as the British constitution to define and defend American rights. On the other side, Joseph Galloway and James Duane argued that American rights derived only from the British constitution and the colonial charters [...] although Jay was generally conservative, as were Galloway and Duane, on this issue Jay sided with the radicals like Adams", John Jay, founding father, op. cit., p. 51.

47 Horst DIPPEL, El concepto de Constitución en los origenes del constitucionalismo norteamericano (1774-1776), publicado en el sexto volumen de la revista Fundamentos, cuadernos monográficos de teoría del Estado, Derecho público e historia constitucional, Junta General del Principado de Asturias, 2010, p. 27-83.

48 JCC, I, 25. 
deliberaciones acordado por el Congreso le impone, no duda en revelar a su interlocutor sus más intimos deseos en cuanto a la solución que ansía para el conflicto: "the indignation of all ranks of people is very much caused by the Boston \& Canada Bills. God knows how the Contest will end. I sincerely wish it may terminate in a lasting Union with Great Britain. I am obliged to be very reserved on this subject by the injunction of secrecy laid on all the members of the Congress, and tho I am aware of the confidence I might repose in your prudence, I must nevertheless sumbit to the controul of honour, perhaps on this occason too delicate."49

Pero, sin duda alguna, la labor más destacada de John Jay en este primer Congreso Continental es la redacción de Address to the people of Great Britain. Sobre este punto, existen dos versiones distintas que explican el cauce seguido para elaborar el trascendental documento. La primera es la ofrecida indirectamente por Thomas Jefferson, y la segunda por el mismo Jay, precisamente a raíz de la publicación de aquélla.

La versión que Frank Monaghan acepta como válida es la que ofrece Thomas Jefferson a William Wirt cuando éste recopilaba información para elaborar la biografia de Patrick Henry. Según Jefferson, el Congreso Continental designó una ponencia de tres miembros para redactar la apelación al pueblo de Gran Bretaña, siendo designados para ello Richard Henry Lee, William Livingstone y John Jay. El primero, de simpatias abiertamente revolucionarias, elaboró una propuesta claramente rupturista, mientras que Jay redactó unas notas pasa uso estrictamente personal en las que consignó sus ideas sobre el particular. Al someterse a la aprobación del Congreso el borrador de Lee, éste es recibido con una manifiesta frialdad, por lo que William Livingston irrumpe súbitamente y manifiesta que desea exponer las notas que "a friend of mine" ha elaborado. Estas notas (que no eran otras que las redactadas por Jay) fueron aprobadas casi sin modificaciones por el Congreso, y remitidas a la metrópoli como Address to the people of Great Britain. De creer a Jefferson, John Jay llegó incluso a abordar violentamente a Lee por entender, equivocadamente, que éste había atribuido la autoría del documento a Livingston ${ }^{50}$.

William Jay, en el esbozo biográfico sobre su padre, no hace referencia alguna a un supuesto rechazo del borrador de Lee, afirmando no existió otra versión que la elaborada por Jay, precisando incluso las condiciones de

49 SPJJ, I, 94-95.

50 "Jefferson recalled, many years later, an argument about this time between Jay and Richard Henry Lee. Jefferson had urged William Livingston to take on a drafting assignment because Livingston was reputed the autor of the Address to the people of Great Britain, which Jefferson considered "the first compositon in the English language". Livingston relayed this comment to Jay who, naturally assumed that it was Lee the other member of the prior year's committee, who was denying Jay the credit for the draft. A few days later, while Jefferson and Lee were talking in he legislative lobby, Jay appoached them. "Talking [Lee] by a button of the coat [Jay] said to him pretty sternly "I understand, sir, that you informed this gentleman that the Address to the People of Great Britain, presented to the committee by me, was drawn by Governor Livingston." Jefferson attempted to calm Jay down, assuring him that "though indeed I have been so informed, it was not $b \mathrm{Mr}$. Lee, whom I had never Heard utter a Word on the subject". Presumably this eased the tension so that Jay released Lee's coat' Walter STARR, John Jay, founding father, op. cit., p. 63. El episodio también lo recogió Frank MONAGHAN en su John Jay, defender of liberty, op. cit., p. 70-71. 
elaboración del documento, para lo cual, el redactor del mismo "to secure himself from interruption, he left his lodgings and shut himself up in a room in a tavern; and there composed that celebrated state-paper"51. Walter Starr, último biógrafo de Jay, pone en duda la versión transmitida por Jefferson, considerándola una historia "bonita, más probablemente incierta". Y justifica su excepticismo de la siguiente forma: "Jefferson's information was second-hand and his account written thirty years later. None of the delegates who were present at Philadelphia, in their contemporary notes or letters, mentioned a rejection of a Lee draft and acceptance of a Jay draft. Jay's own recollection, years later, was that the committee had agreed that Lee would prepare the memorial to the Americans and he would prepare the Adress to the british." 52 En la última edición impresa del fondo documental de Jay, que data del año 2010, la nota introductoria al Address to the people of Great Britain ofrece ambas versiones, pero sin llegar a afirmarlo de forma explícita, se inclina más por la tesis de Starr, argumentando que en una epístola dirigida a John Adams en 1818 el propio Jay negaba rotundamente que se hubiese remitido al Congreso otro documento que el suyo, aunque sí reconocía que "one person in particular that you specify" (divertido circunloquio para referirse a Lee) habia esparcido rumores negando a Jay autoria del proyecto; lo que demuestra igualmente que, bien entrado el siglo XIX, Jay se sentía tan orgulloso de su labor como para mantener viva la ofensa frente a quien sembrara dudas sobre su autoría ${ }^{53}$. Lo cierto es que en la edición del Journal of Continental Congress publicada en 1906 atribuye la redacción de Address to the people of Great Britain a John Jay, y la Memorial to the inhabitants of the British colonies a Richard Henry Lee. El Congreso efectuó así una brillante maniobra que permitiria satisfacer a las dos facciones que la integraban, puesto que Lee, persona cuyas simpatías se inclinaban abiertamente al ala más radical, sería el encargado de redactar el informe con destino a la población americana, con lo que podría de alguna manera contentar al sector más abiertamente rupturista, mientras que en lo que respecta a la metrópoli al atribuir la redacción a Jay, ideológicamente afín al sector más moderado, evitaría roces y malos entendidos con el pueblo y las autoridades inglesas.

Son tres los documentos esenciales que aprueba el primer Congreso Continental durante los días 20 y 21 de octubre de 1774 .

1.- La denominada Association ${ }^{54}$, que en realidad no era otra cosa que un simple boicot comercial a Gran Bretaña. Dicho acuerdo principiaba con expresiones de acatamiento y afecto a las autoridades y ciudadanos británicos ("avowing our allegiance to his majesty, our affection and regard for our fellow subjects in Great Britain and elsewhere"), pero a continuación reflejaba el disgusto y malestar por los agravios que sufria la población colonial, malestar que se atribuía a unas medidas "adoptadas por el ministerio británico en 1763, con el objetivo calculado de esclavizar estas colonias $y$, con ellas, a todo el imperio

51 William JAY, Life of John Jay, op. cit., p. 30

52 Walter STARR, John Jay, founding father, op. cit., p. 54

53 SPJJ, I, p. 96-99. El texto del documento lo reproduce a continuación en las páginas 100107.

54 JCC, I, 75-80. 
británico". Por ello, para obtener el remedio a tales actos que amenazaban con "destruir las vidas, libertad y propiedad de los súbditos de Su Majestad en Norteamérica", se adoptan medidas de naturaleza estrictamente económica: prohibir la importación y exportación de bienes de y hacia Gran Bretaña, si bien en el primer caso la medida se haría efectiva a partir del 1 de diciembre de 177455 y en el segundo caso se demoraba su eficacia hasta el 10 de septiembre de 1775 para no perjudicar a la población inglesa ${ }^{56}$.

2.- El Address to the people of Great Britain elaborado por Jay se aprueba el dia 21 de octubre de 177457 . Se trata de un extenso documento remitido a Gran Bretaña para que ésta reconsiderase sus posturas y anulase la legislación anticolonial de castigo a Massachussets.

Conviene incidir sobre un aspecto esencial: no se dirige al monarca, ni tampoco al Parlamento, sino al "pueblo de Gran Bretaña", lo que se reafirma en la frase inicial del texto, una llamada a sus "friends and fellow subjects." El documento reconoce la lucha de los ingleses por la libertad, y por ello no tiene más remedio que concluir las medidas adoptadas por el Parlamento británico en relación a las colonias implican, bien que se ha cesado en la virtud tradicional inglesa, o bien negligencia de quienes en ese momento la gobiernan.

Las actuaciones del gobierno inglés únicamente tienen por objetivo restringir los derechos de los habitantes de las colonias, de ahí las continuas metáforas vinculadas a simbolos opresivos de la libertad ("forging chains for her friends and children") y a la propia institución de la esclavitud "turns advocate for slavery and oppresion", "enslaving your fellow subjects in America").

Sobre esa base inicial o presupuesto del que parte la petición, es decir, el reconocimiento de la lucha por la libertad que ha caracterizado la historia de Gran Bretaña y lo contradictorio de la misma en relación a su comportamiento presente con los habitantes de las colonias, el Address se centra en las cuestiones básicas que justifican la petición de los colonos:

A.- La equiparación jurídica entre la población inglesa y la colonial. Tras recordar que los firmantes del documento y los destinatarios del mismo "descended from the same common ancestors" y que los antepasados de los colonos han participado igualmente en las luchas por la conquista de la libertad, se llega al núcleo básico sobre el que se sustenta la petición: la población colonial ostenta los mismos derechos que la británica: "we are and ought to be as free as

55 "That from and after the first day of December next, we will not import, into British America, from Great Britain or Ireland, any godos, wares or merchandise whatsoever or from any other place, any such godos, wares or merchandise, as shall have been exported from Great Britain or Ireland; nor will we, after that day, importa $n$ East India tea from any part of the world; nor any molasses, syrups, paneles, coffee, or pimento from the British plantations or from Dominica; nor wines from Madeira or the Wester Islands; nor foreign indigo"

56 "The earnest desire we have, not to injure our fellow subjects in Great Britain, Ireland or the West Indies, induces us to suspend a non-exportation, until the tenth day of September 1775; at which time, if the said acts and parts of acts of the British parliament herein after mentioned are not repealed, we will not, directly or indirectly, export any merchandise or commodity whatsoever to Great Britain, Ireland or th West Indies, except rice to Europe"

57 JCC, I, 82-90 
our fellow-subjects in Britain and that no power on earth has a right to take our property from us without consent [...] we claim all the benefits secured to the subjects by the English law."

B.- Incide en la consideración que los colonos son jurídicamente equiparables al resto de súbditos de Su Majestad Británica: "and do insist, that we are and ought to be, as free as our fellow-subjects in britain, and that no power on earth has a right to take our property from us without our consent." Por lo tanto, no puede tomarse ninguna medida frente a los mismos sin que los colonos hayan manifestado su consentimiento. A partir de ese momento, se mencionan varios derechos fundamentales consagrados en la constitución inglesa (el juicio por jurado, el derecho a no ser condenado sin la oportuna defensa).

C.- Se hace una exposición bastante detallada de los eventos que tienen lugar desde la Guerra de los Siete años hasta el Motín del Té y la aprobación de las Intolerable Acts, a las que el documento ataca con un argumento jurídicamente muy sólido: Gran Bretaña ha actuado incorrectamente al aplicar una solución política a un asunto estrictamente jurídico que atañe únicamente a dos sujetos particulares. Es aquí sin duda alguna donde brilla con luz propia el talento jurídico de Jay quien, incluso admitiendo que los habitantes de Boston hubiesen actuado de forma incorrecta, sostiene que el remedio apropiado era jurídico y únicamente estaba legitimado para adoptarlo la East India Company como persona jurídica afectada; ese remedio no era otro que una acción civil contra los responsables de los daños causados: "Even supposing a trespass was thereby committed, and the Proprietors of the tea entitled to damages - The Courts of Law were open, and Judges appointed by the Crown presided in them. The East India Company however did not think proper to commence any suits, nor did they even demand satisfaction, either from individuals or from the community in general. The Ministry, it seems, officiously made the case their own, and the great Council of the nation descend to intermeddle with a dispute about private property." Este es, sin duda alguna, una atinada y brillantísima tesis dirigida a la línea de flotación de los actos adoptados por el Parlamento inglés: en efecto, nadie había interpuesto acción judicial alguna ante los órganos judiciales de la colonia, cuya imparcialidad no podía ser cuestionada al haber ofrecido un ejemplo de ello tan sólo cuatro años antes, cuando un jurado integrado por colonos americanos había absuelto a los oficiales británicos acusados de asesinar a cinco habitantes de la colonia en lo que ulteriormente fue denominado con notable exageración "matanza de Boston."58

C.- Por último, se efectuaba una apelación directa en forma de súplica para que cesase el "ministerial plan for inslaving us". Confiaban en que existia aún "much virtue, much justice and much public spirit in the English nation. To that justice we now appeal", finalizando con un esclarecedor "permit us to be as free as yourselves."

58 Los hechos ocurrieron el 5 de marzo de 1770, y los oficiales británicos fueron defendidos por John Adams, quien logró que un jurado integrado por habitantes de las colonias declarase no culpables a los soldados ingleses. David McCUlLOUGH, John Adams, Touchtone, Nuva York, 2001, p. 65-68. 
En definitiva, que con este documento se trata de hacer ver al pueblo británico de forma muy respetuosa pero a la vez muy firme, que la población colonial americana está siendo injustamente tratada, pues se les están privando injustamente de los derechos que como súbditos ingleses poseen.

3.- La Memorial to the Inhabitants of the British colonies ${ }^{59}$, redactado por Richard Henry Lee, aprobada a la vez que la anterior. En algunos puntos esta apelación al pueblo de las colonias adelanta puntos que se recogerán con posterioridad en la Declaración de Independencia un par de años más tarde (por ejemplo, la invocación a Dios y la necesidad de justificar aquellos casos en los que el pueblo muestra su oposición al gobierno ${ }^{60}$, o la referencia a "these truths"). El documento plantea una cruda disyuntiva entre el silencio culpable (que supondría traicionar a la población colonial) o la censura del comportamiento de los gobernantes, pese a lo cual no se rehúye tomar partido por la última de las opciones $^{61}$. Se hace a continuación un exhaustivo análisis de las medidas tomadas por el Gobierno inglés desde el final de la Guerra de los Siete Años hasta la aprobación de las Intolerable Acts, medidas que el documento considera "astonishing and unjustifiable, when it is considered how unprovoked it has been by any behaviour of these Colonies." Se trata, por tanto, de un ataque gratuito e injustificado a la población colonial que pretende subyugarla, privándole de los derechos que posee cualquier otro ciudadano inglés, algo injusto teniendo en cuenta el sacrificio que los colonos americanos habían efectuado en la pasada guerra dado que, no olvidemos, el territorio americano fue frente de batalla entre franceses y británicos. Es por ello que esas medidas adoptadas por el Parlamento inglés frente a las colonias llegan a ser expresamente calificadas de "injurious and irritating to this devoted country. Under pretence of governing them, so many new institutions, uniformly rigid and dangerous, have been introduced, as could only be expected from incensed masters, for collecting the tribute or tather the plunder of conquered provinces". La crudeza de los términos no deja lugar, pues, a la menor duda en cuanto al estado de ánimo de las distintas colonias. Pero, con todo, casi al final se desliza un argumento de apariencia baladí, pero que conlleva en el fondo toda una carga de profundidad: el gobierno inglés opta por castigar a la ciudad de Boston y a la colonia de Massachussets, pero no adopta medida alguna frente al resto de las colonias aún cuando éstas mantienen el mismo espíritu de oposición que aquélla62; el gobierno inglés trata, por tanto, de personalizar en una sola colonia. Finalmente, y aun cuando se argumenta que dado la razón se

\footnotetext{
59 JCC, I, 90-100.
}

60 "In every case of opposition by a people to their rulers, or of one state to another, duty to Almighty God, the creator of all, requieres that a true and impartial judgment be formed of the measures leading to such oposition; and of the causes by which it has been provoked or can in any degree be justified"

61 "We find ourselves reduced to the disagreeable alternative, of being silent and betraying the innocent, or of speaking out and censuring those we wish to revere. In making our choice of these distressing difficulties, we prefer the course dictated by honesty, and a regard for the welfare of our country."

62 "It is pretended that the province of Massachusetts-Bay has been particulary disrespectful to Great-Britain, yet in truth the behaviour of the people, in other colonies, has been an equal opposition to the power assumed by parliament. No step, however has been taking against the rest." 
inclina de parte de los colonos éstos pudieran adoptar otras medidas, se limitan a aprobar las que finalmente acuerdan, más que nada en aras a que sea el propio Gobierno inglés quien reflexione y dé marcha atrás voluntariamente. Como puede verse, Lee utiliza un lenguaje mucho más incisivo que Jay, comprensible tanto por las distintas filias de ambos autores como, en medida no desdeñable, por ser los destinatarios de ambos colectivos muy distintos.

El sábado 22 de octubre de 1774, a punto de finalizar las sesiones, el Congreso acuerda la convocatoria automática de un segundo Congreso que se reuniría el día 10 de mayo del año 1775, salvo para el caso que las autoridades inglesas rectificasen las medidas adoptadas en contra de las colonias. Tan poca debia ser la confianza que los delegados tenian en lo que al particular respecta, que se recomendaba a las colonias que "eligiesen lo antes posible" los representantes para el nuevo Congreso.

Una vez finalizado el primer Congreso Continental, los delegados del estado de Nueva York dirigen un memorial tanto al Dutchess County Freeholders como al Committee of the Mechanics ${ }^{63}$. Dichos textos aúnan tanto un agradecimiento de los delegados a las autoridades que les designaron como una rendición de cuentas de su actividad, que manifiestan haber desempeñado "with zeal and fidelity, with a fervent regard to the interest and happiness of our country". Justifican la necesidad y oportunidad de actuación debido a la excepcional situación opresiva que viven las colonias: "our common liberties invaded, our dearest rights in danger, and a whole continent loudly called upon to defend and secure themselves against hich handed oppresions." Pese a ello, en modo alguno se considera que la situación aboque irreversiblemente a la ruptura, puesto que no rehusan manifestar "their veneration for the parent State" y calificar la situación como "unhappy", justificada no obstante por "the principles of selfpreservation and into which are innocently plunged by the artful wiles of an infatuated and tyranical ministry".

La importancia del primer Congreso Continental para John Jay fue, por tanto, decisiva, pues facilitó no sólo que su nombre adquiriese relevancia política extramuros de la colonia de Nueva York, sino que le catapultó a primera línea de la politica norteamericana64. Jay nunca ocultó sus preferencias ni sus más íntimas convicciones, ni en público ni en privado, y estas no eran otras que las compartidas con la facción conservadora: el deseo de que Gran Bretaña rectificase su política colonial y lograr un acuerdo con la metrópoli. No obstante, en privado Jay reconocía estar "harto" de política, y buena prueba de ello es la carta que el 1 de enero de 1775 dirige a Robert Livingston, una carta de naturaleza estrictamente personal en la que repasaba los acontecimientos que jalonaron la amistad y el carácter de ambos, misiva que finalizaba con esta observación: "I ought to say something to you about politics, but I'm sick of the subject."65

63 El texto del primero en SPJJ, I, 107-108.

64 "Congress terminated its labours in about six weeks; and in this brief period, Mr. Jay had acquired the confidence of his countrymen by the ability and zeal he had manifested in their service"; William JAY, Life of John Jay, op. cit., vol I, p. 30.

65 SPJJ, I. 111. 


\section{3.- E1 Segundo Congreso Continental: la Letter from Congress to the opressed inhabitants of Canada y la Olive branch petition.}

En la ciudad de Nueva York, el 22 de noviembre de 1774 un Comité integrado por sesenta miembros (es decir, el creado en mayo de ese año, pero aumentando en una decena sus componentes), entre los cuales se encuentra John Jay, es el encargado de ejecutar y velar por el cumplimiento del boicot comercial acordado en Filadelfia.

En el año 1775, llegado el momento de elegir a los delegados de la colonia al nuevo Congreso, el meritado Comité no se considera con la autoridad suficiente para ello, por lo que el 1 de marzo se convoca una reunión de ciudadanos y propietarios a fin de que fuesen éstos los encargados de pronunciarse sobre el método adecuado para la elección. Los ciudadanos son quienes se inclinan por la convocatoria de elecciones para elegir representantes a un Comité de toda la colonia que, a su vez, eligiese a los delegados al Congreso. Los sufragios se celebran el día 15 de marzo, y entre las personas elegidas para el Comité colonial de Nueva York se encuentra Jay.

En abril, dicho Comité no sólo elige a las doce personas encargadas de representar a Nueva York en el segundo Congreso Continental, sino que aprueba igualmente las instrucciones a los mismos, autorizando a todos ellos "or any five of them" para adoptar en el Congreso "such measures as shall be judged most effectual for the preservationd and re-establishment of American rights and privileges and the restorarion of harmony between Great Britain and the colonies"66. No obstante, cuando el 23 de abril llegan a la ciudad de Nueva York las noticias de los acontecimientos de Lexington y Concord, el Comité de los sesenta encargado de gobernar la ciudad amplía sus miembros hasta los cien y, como era previsible, John Jay se encuentra entre ellos. Este último comité colonial es el que, con la denominación Provincial Congress, se reunirá en Nueva York asumiendo las funciones estatales.

El segundo Congreso Continental inicia sus sesiones el miércoles día 10 de mayo de 1775, aunque Jay no se incorpora hasta tres días más tarde, el 13 de mayo. Su tarea va a ser tanto o más intensa que en el primero, como tanto o más intenso fue el propio Congreso, que hubo de lidiar ya con un enfrentamiento bélico abiertamente declarado. Pero, a diferencia de lo que ocurrió el año anterior, Jay va a tener una parte muy activa en el desarrollo politico-constitucional de la colonia de Nueva York, hasta el punto de que su estancia en Filadelfia no le impedirá otear la evolución de su estado natal, cuya actuación orientará desde el primer momento al haberse convertido en uno de los nombres claves de la política neoyorkina. En una carta que a Jay dirigió Samuel Kissam (hermano de su antiguo preceptor en la abogacia) el 31 de octubre de 1775 se contiene la mejor descripción tanto de la relevancia que a nivel supracolonial había adquirido John Jay como de la situación del Imperio británico; pues mientras a nivel

66 Walter STARR, John Jay, founding father, op. cit., p. 58. Las instrucciones de los delegados neoyorkinos constan en los despachos acreditativos de su condición, y fueron reflejadas, junto con las de los representantes de las otras colonias, en la sesión del jueves 11 de mayo de 1775; JCC, II, 15-16. 
estrictamente personal Kissam manifestaba su alborozo por la inclusión de Jay entre los delegados al Congreso Continental, a nivel político y en lo que atañe a las relaciones con la metrópoli, en dicha misiva se destacaba la siguiente frase: "...I think it plain to observ'd that great Britain has pass"d the meridian of her Glory; and why would not America (like the Phenix) arise to a great empire from the ashes of its mother." 67

Aunque sin duda no era esa aún la opinión de Jay, quien aún no había perdido la esperanza de alcanzar una solución negociada del conflicto que permitiese restaurar la paz con la metrópoli. Sin embargo, la división entre los propios colonos americanos alcanzaba ya una notable intensidad.

En la sesión del día 26 de mayo de 1775 Jay es elegido, junto con Silas Deane y Samuel Adams, para redactar una proclama con el objeto de atraerse a la población del Canadá, lo que daría lugar a la Letter to the oppressed Inhabitants of Canada. El texto definitivo se aprueba en la sesión del 29 de mayo y como tal se insertó en el Journal of Continental Congress ${ }^{68}$, aunque también se publicó como panfleto en las diversas publicaciones coloniales de la época.

Este documento, pretende equiparar la situación que viven los colonos americanos a la canadiense, de ahí que se utilicen expresiones que vinculen o equiparen los agravios a la población de ambos lugares: ("sense of common danger", "defense of our common liberty", "fellow suffers with us") en un intento claro de granjearse la simpatía canadiense. De igual forma, y al igual que en la Address to the People of Great Britain, abundan las metáforas que equiparan las agresiones británicas con la institución de la esclavitud, de ahí que se hable de un "plan for subyugating the continent", "fetters of slavery" asi como que "you and your wives and your chilfren are made slaves". Para evitar un conflicto derivado de la diferencia religiosa, Jay (que pese a sus profundas convicciones religiosas vinculadas a la ideologia protestante siempre hizo gala de una antipatía manifiesta por la confesión católica) mitiga su anticatolicismo, limitándose a indicar que "protestant and catholic colonies to be strongly linked together."

La solicitud de apoyo a la población canadiense no oculta que la causa americana es la causa de la libertad, y que a ella vinculan su propia existencia ("for our parts, are determined to live free, or not at all") tras lo cual se hace una manifestación que, sin duda alguna, refleja el pensamiento de Jay, pero no el de todos sus compañeros de lucha: "posterity shall never reproach us with having brought slaves into the world." Finalmente, se apela a la bravura y al honor de los habitantes del Canadá para que sumen sus esfuerzos a los de los colonos: "We can never believe that the present race of canadians are so degenerated as to possess neither the spirit, the gallantry, nor the courage of their ancestors."

No fue esta la única misiva que se remitió a los pueblos de otras naciones. Se elaboraron apelaciones similares a los pueblos de Irlanda y Jamaica pero su

67 SPJJ, I, 152.

68 JCC, II, 68-70. 
atribución a Jay es, en palabras de uno de sus biógrafos, "altamente improbable."69

Con posterioridad, el El 3 de junio de 1775 se nombra un Comité de cinco personas (John Dickinson, John Rutledge, Thomas Johnson, John Jay y Benjamin Franklin) para redactar una nueva petición al monarca inglés ${ }^{70}$. Jay elaboró un borrador en el que se refería a los colonos americanos como "subjects bound to your Majesty by the strongest ties of allegiance \& by affection and attached to their Parent Contry by every bond thant can unite Societies" que apelan al "paternal Care of their Prince and the Justice of the British Nation", y aún cuando manifiesta el deseo de los habitantes de norteamérica de vivir en libertad, reconoce la autoridad del Parlamento británico para regular las actividades comerciales ("altho the people of North America are determined to be free they wish not to be independent and beg leave again to assure his Majsty that they mean not to question the Right of the British Parliament to regulate the Commercial Concerns of the Empire to the Manner they have before declared, as their enemies have unkindly insinuated"), de ahi que abogase por un acuerdo que permitiese: "the present unnatural contest end in a compact that may place the Union of the Empire on a firm \& permanent basis" 71 En esta ocasión, el Congreso aprobó finalmente el día 8 de julio el texto presentado por John Dickinson, que la historiografia norteamericana conoce como la Olive branch petition, una exposición al monarca inglés redactada en un tono muy cortés pero firme, solicitando la derogación de la legislación anticolonial, y dejando expresamente abierta la reconciliación con Inglaterra. ${ }^{72}$ La versión final aprobada por el Congreso mantiene la idea esencial de Jay en el sentido de abogar por una solucion pacífica que permitiera mantener vigentes los lazos de unión con Inglaterra ${ }^{73}$, pero se elimina del texto final la aceptación de la autoridad del Parlamento inglés.

A finales de octubre de 1775, Jay fue nombrado coronel del segundo regimiento de la milicia de Nueva York. Y en esos momentos tuvo un papel fundamental a la hora de mantener la unidad de acción de las colonias en su lucha frente a la metrópoli. Nueva Jersey había aprobado dirigir unilateralmente

69 Frank MONAGHAN, John Jay, defender of liberty, op. cit., p. 72

70 JCC, II, 80.

71 SPJJ, I, 123-124.

72 JCC, II 158-161. El Comité Provincial de Nueva York había remitido el día 29 de junio de 1775 a los representantes que dicho estado tenía en el Congreso Continental una carta a la que adjuntaba un documento o propuesta para alcanzar un acuerdo con Gran Bretaña, documento en el que se reconocía (de igual manera que Jay en su borrador de petición al monarca inglés) la autoridad del Parlamento para regular la actividad comercial, pero reservaba la potestad tributaria a las colonias. La misiva del Comité puede encontrarse en SPJJ, I, 123-124.

73 Según William JAY, "Mr Jay, however, mantained that if the people were called to take up arms against their sovereign, they ought to be persuaded that sus a measure was unavoidable, and should it be found necessary after the colonies to separate from Britain, the conviction that no proper efforts to prevent such an event had been ommited..."; Life of John Jay, op. cit., p. 36. No obstante, Jay aún confiaba que con esta segunda petición las autoridades británicas reconsiderarian su decisión y se alcanzaría un acuerdo que restableciese la armonía entre Gran Bretaña y sus colonias; Frank MONAGHAN, John Jay, defender of liberty, op. cit., p. 73 
y de forma exclusiva una petición al monarca inglés, aunque finalmente fue disuadida de ello ${ }^{74}$.

A raíz de este episodio elaboró a finales de diciembre unas notas relativas a los intentos de los enemigos de la causa americana por fomentar la división entre las colonias, documentando todos los intentos al respecto, aunque finalmente el mismo no llegó a publicarse ${ }^{75}$. Ese documento, titulado significativamente Proofs that the Colonies do not aim at independence, pretendia acreditar que el movimiento de reivindicación colonial en modo alguno tenía como objeto cercenar los vínculos con Gran Bretaña, y que esa era una idea que los enemigos de la libertad imputaban a los colonos para sembrar la discordia entre ellos. Jay incidía en que un simple vistazo a los diarios de sesiones del Congreso permitirian desechar esa idea, y hace una recopilación de toda una serie de iniciativas y actividades donde aparece constatado que el deseo último de los rebeldes no es otro que lograr resolver pacíficamente una situación que califican de "unhappy" y que el objetivo a lograr es restaurar la "armonía" entre los colonos y su metrópoli.

Con todo, la actividad politica en el Congreso Continental estuvo a punto de afectar a la vida privada de Jay. Su deseo de pasar las navidades junto a su esposa, embarazada ya de ocho meses, se vio frustrado por el hecho de que el Congreso Continental mantuvo su actividad en esas fechas, lo que motivó que dirigiese a su mujer una carta fechada el 23 de diciembre de 1775 comunicándole tal circunstancia, pero indicandole con total determinación que: "It is however some consolation that should the Congress not adjounr in less than ten days, I am determined to stay with yú till... and depend upon it nothing but actual imprisonment will be ale to keep me from you." "76 No obstante, la cuestión se solucionó al poco tiempo, pues a principios de enero de 1776 llega a Filadelfia el acuerdo adoptado por el Congreso Provincial de Nueva York en virtud del cual considera suficiente la presencia de tres delegados para representar a la colonia en el Congreso ${ }^{77}$, por lo que, al contar en ese momento Nueva York con otros cuarto representantes, tal circunstancia permitió a Jay regresar a Elisabethtown. No obstante, antes de abandonar Filadelfia, el 4 de enero de 1776 escribía una carta a su hermano James y en la cual, tras indicar que no desea abordar cuestiones políticas, deja bien claro su pensamiento sobre el conflicto: el objetivo último es la reconciliación con Inglaterra pero, si ello no es posible, ello supondrá reducir el imperio británico "to pieces"78. Poco después, abandonaba la capital de Pennsylvania para regresar junto a su esposa, que el 24 de enero de 1776 da a luz a su primer hijo,

74 David MONAGHAN, John Jay, defender of liberty, op. cit., p. 77-78.

75 SPJJ, I, 174-177.

76 SPJJ, I, 187-188. Por cierto, que en esa misma carta Jay indica que el Comité Provincial de Nueva York ha decidido abonar a los delegados cuatro dólares diarios por asistencia al Congreso, lo que implica que hasta el momento cada uno de los representantes debía sufragar con su propio patrimonio los gastos en que incurría por ejercer la representación.

77 Walter STARR, John Jay, founding father, op. cit., p. 80.

78 "tho'We desire Reconciliation, are well prepared for contrary measures. This is an unnatural quarrel, \&God only knows why the British Empire should be torn to piedes by unjust attemps to subjugate us". SPJJ, I, 195. 
Peter Augustus. Tras su paternidad, Jay permaneció un par de meses junto a su esposa.

En marzo de 1776 vuelve a Filadelfia para ejercer las labores como representante de Nueva York en el Congreso Continental, donde permanecerá un par de meses. Interesa destacar en este periodo su rotunda afirmación de la preeminencia del poder civil sobre el militar, lo que es muy significativo si tenemos en cuenta que los Estados Unidos se encontraban inmersos en un conflicto bélico. En efecto, en marzo de ese mismo año el general Charles Lee comenzó a exigir un juramento de fidelidad a la población colonial, algo que el Congreso Continental rechazó de plano al adoptar el día 9 de marzo de 1776 una resolución según la cual "no oath by the way of test be imposed upon, exacted, or required of any of the inhabitants of these colonies, by any military officers."79 John Jay, al hacerse eco de tal resolución en una carta escrita tres días después a Alexander McDougall, iba aún más lejos al indicar que de haberse mantenido la exigencia no sólo se estarian usurpando atribuciones que corresponderian al Congreso, y que en el momento en que el ejército usurpa funciones que corresponden al legislativo, estaría esclavizando a la población ${ }^{80}$. En el mes de abril, cuando aún se encontraba en Filadelfia, Jay es elegido representante por la ciudad y el condado de Nueva York al Congreso colonial de Nueva York, al que se incorporaría a finales del mes siguiente. Y es que en mayo de 1776 regresaría a su hogar, prolongándose su estancia en el mismo no sólo por cuestiones de naturaleza personal (la enfermedad de su padre Peter y de su esposa Sarah), sino también por motivos estrictamente políticos pues, como señala uno de los biógrafos de Jay, "instead of returning to Continental Congress in Philadelphia, he decided to attend the sessions of the Provincial Congress in New York City. In part this was a question of proximity; he wanted to be near his family. But it was also a question of priority: he believed that the New York Provincial Congress needed him more than Continental Congress" 81 Esta ausencia de Jay, una figura clave entre el sector moderado de la resistencia, se va a dejar sentir precisamente en unos momentos en que la difusión del opúsculo Common sense, escrito a principios de ese año 1776 por el británico Thomas Paine, va a influir decisivamente a la hora de reforzar las tesis de quienes abogan por romper abiertamente todo lazo de unión con la metrópoli.

El día 15 de mayo de 1776 el Congreso Continental va a adoptar una decisión crucial que supone ya un punto de no retorno en el conflicto con la metrópoli: se disuelven los lazos con la Corona inglesa y se deposita la autoridad que hasta entonces ostentaba inglaterra en la población colonial, lo que se hace en términos muy claros:

"whereas it appears absolutely irreconcileable to reason and good conscience for the people of these colonies now to take the oaths and affirmations necessary for the support

79 JCC, IV p. 195.

80 "The Resolucion of Congress restraining military officers from offering oaths by way of test to the inhabitants I hope has reached you. I cant account for your Convention's submitting to this usurpation on the rights of their constituents -to impose a test is an sovereing act of legislation-and when the army become our legislators, the people that moment become slaves", SPJJ, I, 209.

81 Walter STARR, John Jay, founding Father, op. cit., p. 74 
of any government under the crown of Great Britain, and it is necessary that the exercise of every kind of authority under the said crown shoud be totally suppressed, and all the powers of government exerted, under the authority of the people of the colonies, for the preservation of internal peace, virtue and good order, as well as for the defence of their lives, liberties, and properties against the hostile invasions and cruel depredations of their enemies." 82

Los representantes de la colonia de Nueva York parecían encontrarse desconcertados, y a este respecto es sumamente ilustrativa la carta que Edward Rutledge le dirige el día 29 de junio de 1775 instándole a que acuda a Filadelfia ante la perspectiva de que se someta a votación "A Declaration of independence, the form of a Confederation of these olonies, and a Scheme for a Treaty with foreign Powers"; Rutledge, hermano de un futuro juez del Tribunal Supremo de los Estados Unidos, reconocía "perfectamente" que la presencia de Jay sin duda alguna era útil en Nueva York, pero intenta forzar su voluntad apelando tanto a la importancia de los asuntos a debatir como a la escasa entidad de los representantes de la colonia: "Recollect the manner in which your Colony is at this Time represented: Clynton has Abilities bit is silent in general, and wants (when he does speak) that influence to which he is intitled. Floyd, Wisner, Lewis and Alsop tho'good Men, never quit their Chairs. You must know the Importance of these Questions too well not to wish to be present whilst they are debating...." Por cierto, Rutledge aprovecha para manifestar a Jay su pensamiento en cuanto a las prerrogativas o potestades a atribuir al Congreso, que deberían ser las mínimas para que todo el poder continuase residiendo en los estados: "I am resolved to vest the Congress with no Power than what is absolutely necessary, and to use a familiar expression to keep the Staff in our own Hands; for I am confident if surrendered into the Hands of others a most pernicious use will be made of it." 83 Jay acusa recibo de dicha carta y responde a la misma el día 6 de julio pese a estar inmerso en "plots, conspiracies and Chimeras dire, that, thoush I thanked hyou for it in my head I had no time to tell you so either in person or by letter"; en cuanto a su presencia en el Congreso, aunque lamenta la misma, se disculpa dejando, además, en la incertidumbre su posible regreso al foco de politica intercolonial, dado que en esos momentos lo más importante es la propia creación del estado de Nueva York: "How long I may be detained here is uncertain, but I see little prospect of returning to you for a month or two yet to come. We have a government, you kow, to form; and God only knows that it will resemple."84

$\mathrm{Su}$ ausencia se dejaría sentir, y en varias ocasiones sus colegas en el Congreso lamentaron por carta su ausencia y el deseo de que Jay hubiese permanecido con ellos en Filadelfia ${ }^{85}$. Ello es una muestra evidente de la relevancia y el prestigio que John Jay había adquirido en la política norteamericana en apenas un par de años.

82 JCC, IV, 357-58

83 SPJJ, I, 260-261.

84 SPJJ, I, 263-264. Según indica su último biógrafo, Walter Starr," he view the formation of a new state government more important that the wording of a declaration of independence"; John Jay, founding father, op. cit., p. 78.

85 "I wish you had done with your convention. You are really wanted exceedingly in Congress"; carta de Robert Morris, 4 de febrero de 1777, SPJJ, I, 359. 


\section{V.- ARTICULANDO JURÍDICAMENTE EL ESTADO DE NUEVA YORK (1776- 1779). REDACTOR DE LA CONSTITUCIÓN DE 1777 Y PRIMER CHIEF JUSTICE.}

\subsection{Nacimiento del Estado de Nueva York y la Address of the Convention of the Representatives of the State of New York to their Constituents.}

La transformación de Nueva York de colonia británica a estado independiente se hizo en unas circunstancias históricas muy complejas. A finales de 1776 las tropas británicas invadieron parte del territorio neoyorkino, y dicha ocupación por el ejército inglés se mantuvo hasta el fin de las hostilidades. De ahí que la lucha se librase en un doble frente: el bélico (frente a los enemigos externos) y el político (frente a la población leal a los británicos). En Nueva York, además, existía un amplio grupo de simpatizantes probritánicos, y la división entre rebeldes americanos (whigs) y leales a los ingleses (tories) se encontraba tan equilibrada que el 17 de julio de 1775 Robert Livingston se lamentó por carta ante Jay por ello: "I am sorrey to say that the spirit of torysm is far from being subdued in this province [...] I from my own part, I dread a division among ourselves more than the power of Great Britain"86

El 15 de mayo de 1776, el Congreso Continental había aprobado una resolución según la cual, ante los reiterados incumplimientos de la Corona inglesa y la significativa circunstancia ni tan siquiera haber obtenido respuesta a las peticiones de los colonos, rompe ya abierta y definitivamente con Gran Bretaña, haciendo un llamamiento directo a las colonias para que "bajo la autoridad del pueblo", asuman los poderes hasta entonces ejercidos por las autoridades británicas. Y lo hace en los siguientes términos: "whereas it appears absolutely irreconciliable to reason and good Conscience, for the people of these colonies now to take the oaths and affirmations necessary for the support of any gvernmente under the Crown of Great Britain, and it is necessary that the exercise of every kind of authority under the said crown should be tottally suprressed, and all the powers of government exerted, under the authority of the people of the colonies, for the preservarion of internal peace, virtue, and good order, as well as for the defence of their lives, liberties and properties, against the hostile invasions and cruel depradations of their enemies" 87.

El Congreso Provincial de Nueva York se reúne el día 14 de mayo de 1776, aunque no logra el quorum de asistencia necesario hasta cuatro días más tarde, y Jay, elegido para el mismo, no se incorpora hasta el día 25. Todavía en estos momentos, es decir, cuando existe ya un conflicto bélico abierto entre los colonos y la metrópoli, y cuando ha de debatirse la plena asunción por la colonia de las potestades hasta entonces ejercidas por la Corona británica, Jay contempla dicha medida como algo temporal o transitorio hasta lograr un acuerdo de paz. Así lo

\footnotetext{
86 SPJJ, I, 129.

87 JCC, IV 357-358.
} 
plasmó en sendas cartas escritas a James Duane el 29 de mayo de $1776^{88}$, justo un dia después de que una Declaración del Congreso Provincial de Nueva York reconociese que: "the right of government resided in the people". Dicho ente público había confiado a Jay la presidencia del Comité encargado de investigar los complots y conspiraciones probritánicas, facultando a dicho organismo para detener, enjuiciar e incluso sentenciar a sospechosos de espionaje ${ }^{89}$. Como integrante de dicho comité Jay se vio en ocasiones en la penosa obligación de investigar a quienes fueron sus amigos, como Peter Van Shaak, aunque ello no implicó que se cortasen las relaciones ${ }^{90}$.

En este punto, no deja de ser curiosa la justificación que ofrece Walter Starr frente a algunos excesos e injusticias que dicho comité perpetró: "usually no man was more interested in fairness than Jay, but these were unusual and dangerous days, so he may perhaps be forgiven for ocusing on results rather than process" 91 Algo parecido habia apuntado el anterior biógrafo de Jay, Frank Monaghan, para quien "he was a man of peace, but it was characteristic of the troubled period that men were often pressed into services for which they had either experience nor knowledge." 92 Cierto es que Jay era un hombre de paz y opuesto por principio a la guerra por motivos fundamentalmente religiosos, pero ello no excluía que en determinados supuestos la necesidad impusiese la lucha armada en defensa de unos principios sagrados, aún en contra de los más íntimos deseos. De ahí que determinados conflictos armados pudiesen tener una justificación ${ }^{93}$.

E1 9 de julio de 1776 Jay es nombrado Presidente de un Comité encargado de analizar una misiva de los representantes de Nueva York en el Congreso Continental, a la que adjuntan la Declaración de Independencia. El Comité, con el apoyo expreso de su Presidente, decide aceptar el acuerdo y Jay redacta una declaración el día 9 de julio de 1776 en la que deja traslucir sus ideas sobre el particular. Se trata de una medida extrema y no deseada, pero necesaria y que, por tanto, a partir de este momento era preciso defender: "Resolved, unanimosly, that the reasons assigned by the Continental Congress for declaring the United Colonies free and independent States are cogent and conclusive; and that wehile we lament the cruel necessity which has rendered that measure unavoidable, we approve the same, and will, at the risk of our lives and fortunes, join with the other Colonies in supporting it."94 Al dia siguiente, 10 de julio de 1776, se acuerda

88 "So great are the inconveniences resulting from the present mode of Government, that I believe our Convention will almost unanimously agree to institute a better, to continue till a peace with Great Britain shall render it unnecesary", SPJJ, I, 243.

89 Frank MONAGHAN, John Jay, defender of liberty, op. cit., p. 82.

90 En el caso de Van Shaak, éste hubo de exiliarse a Gran Bretaña, aunque con posterioridad pudo volver a territorio estadounidense. Van Shaak no sólo mantuvo la amistad con Jay, que apoyó abiertamente su candidatura en las elecciones para el cargo de Gobernador de Nueva York. SPJJ, I, 318-320.

91 Walter STARR, John Jay, founding father, op. cit., p. 77

92 Frank MONAGHAN, John Jay, Defender of liberty, op. cit., p. 87.

93 Es interesante el diálogo epistolar que sobre el tema mantuvo con John Murray jr entre 1816 y 1818. El mismo aparece detallado en Carol BRIER, Mr Jay of Bedford, op. cit., p. 145-166.

94 SPJJ, I, 266. 
mutar la nomenclatura del órganismo, que de ser el Provincial Congress of the Colony of New York pasa a denominarse Convention of the Representative of the State of New York. Esta fecha puede considerarse, por tanto, como el momento fundacional del empire state.

Jay daba así el paso decisivo, traspasando el Rubicón ${ }^{95}$ y tomando una medida que siempre consideró debía retrasarse lo más posible hasta que las circunstancias la hiciesen inevitable. En la segunda década del siglo XIX, ya en el ocaso de su vida, afincado en Bedford tras retirarse de la vida pública, y con los Estados Unidos ya sólidamente asentados como nación reconocida por las potencias europeas, Jay continuaba fiel a una idea que jamás le abandonó: "It has always been and still is my opinion and belief, that our country was prompted and impelled to independence by necessity, and not by choice."96 No obstante, el hecho de que desease romper los vínculos politicos y jurídicos con Gran Bretaña, no implicaba que desease cortar de raíz todo acuerdo comercial, y mucho menos perjudicar al país que antaño había acogido en su seno a los antepasados de Jay cuando estos sufrieron persecución por motivos religiosos: "I view a return to the domination of Britain with horror \& would risk all for independence but that point ceded, I would give them advantages commercial terms. The destruction of old England would hurt me. I wish it well, it afforded my ancestors an assylum from persecution."97

A partir de julio de 1776 va a dedicarse con todas sus fuerzas tanto a luchar por la causa americana como por articular juridicamente el estado de Nueva York, abogando por desligarse del juramento de lealtad a la Corona británica trasladando ya expresamente las lealtades a los Estados Unidos de América. Walter Starr indica a este respecto que Jay "was completely sincere from 1774 through early 1776, when he declared his personal loyalty to Britain and the British King. But he was also utterly committed to preserving what he saw as traditional British rights, such as the right to elect one's own legislators, or to be tried by one's own peers. When faced with the dificult choice between the British King and the British freedom, he chose freedom. More precisely: he chose to fight for freedom." 98

Jay y los rebeldes neoyorkinos tenían ante sí la tarea de articular jurídicamente un nuevo estado. No obstante, durante el segundo semestre del año 1776 lo que ocupó y preocupó a los habitantes de Nueva York fueron las cuestiones estrictamente militares, dado que Nueva York pasó a convertirse en el centro de operaciones militares al ser ocupado por tropas británicas debido tanto a motivos geoestratégicos como sociales, puesto que un sector no desdeñable de la población de dicha colonia simpatizaba con los británicos. Por ello, los patriotas americanos hubieron de desplegar una doble actividad, por un lado, la

95 Esta referencia al célebre episodio de Julio César fue invocado expresamente por Jay el 22 de febrero de 1777 en el seno del Committee for Detecting Conspiracies, donde manifestó: "Sir, we have passed the Rubicon and it is now necessary every man take this part, cast off all alliegiance to the King of Great Britain and take an oath of Aliegiane to the States of America or go oer to the Eemy for we have Decclared ourselves independent"; SPJJ, I, 363.

$96 \mathrm{CPP}, \mathrm{IV}, 442$.

97 Carta a Governeur Morris, 29 de abril de 1778, en SPJJ I 514.

98 Walter STARR, John Jay, founding father, op. cit, p. 79. 
defensa física del territorio frente a los ejércitos ingleses, y la segunda, la lucha contra el enemigo interior partidario de los británicos. El papel de Jay en ambas fue decisivo, al ser miembro tanto del Committee of Safety (encargado de la defensa militar) como del Committee for Detecting Conspiracies (que tenia en sus manos el contraespionaje), algo que le situará, en palabras de su biógrafo Walter Starr, "far closer to the front lines of the Revolution than is gnerally assumed." 99 Por cierto, y como dato curioso a tener en cuenta, esta labor de Jay en tareas de contraespionaje tendrian su reflejo en el mundo literario, pues en la segunda década del siglo XIX, John Jay suministró al ya célebre escritor James Fenimore Cooper varios datos con los que éste elaboraria su novela The Spy: a tale of natural ground ${ }^{100}$, cuyo protagonista está claramente inspirado en Enoch Crosby, un colono que fingió unirse a los probritánicos pero que en realidad sirvió como espía de los líderes independentistas. Como indica a este respecto Elisabeth $\mathrm{M}$. Nuxoll al referirse a este episodio: "Correspondence between William Jay and Susan Cooper in 1854 revealed that the conversation between Cooper and Jay sggested not only the character of the spy, but also important themes from the novel, particulary the importance of patriotism and civic virtue."101

El mes de diciembre de 1776, tras las derrotas militares americanas en territorio neoyorkino, vio aparecer dos opúsculos con la finalidad de combatir el desánimo. El primero, obra del polemista británico Thomas Paine, es el primer número de una serie que se titularia The American Crisis ${ }^{102}$. Utilizando un estilo crudo, directo e incisivo que apelaba directamente al corazón de los patriotas, buscaba enardecer los ánimos de la población colonial y evitar el decaimiento indiciendo en dos puntos básicos que enunciaba al comienzo de su breve panfleto: por un lado, el deseo de Gran Bretaña no sólo de subyugar fiscalmente a las colonias, sino de colocarlas en una situación bastante cercana a la esclavitud; por otro, concienciar a la población de que la lucha por la independencia no iba a ser un paseo militar o un lecho de rosas, y que cuanto más trabajo costase alcanzar el triunfo final, más dulce sería éste.

El segundo, obra de John Jay, es el Address of the Convention of the Representatives of the State of New York to their Constituents. Este ultimo comparte en cuanto al fondo las mismas tesis de Paine (la intención última de Gran Bretaña no es otra que someter a los colonos no a la esclavitud formal, aunque sí a algo muy parecido a ella y en lo duro de la lucha), pero su estilo es mucho más depurado, abundante en metáforas bíblicas y referencias históricas $\mathrm{y}$, sobre todo, impregnado de principio a fin de continuas invocaciones a Dios. De

99 Walter STARR, John Jay, founding father, op. cit., p. 84-85.

100 Hay edición española, aunque ya algo lejana en el tiempo. El espia: episodio de la guerra de independencia norteamericana, Círculo de Amigos de la Historia, Madrid, 1970. No obstante, dicha edición omite la introducción que Cooper hizo en marzo de 1849, donde apunta sin nombrarlo a la fuente de información para su novela. Cooper indica que durante muchos años, "the writer of this volumen was at the residence of an illustrious man, who had been employed invarious situations of high trust during the darkest days of the American Revolution", precisando ulteriormente que durante esos años "was named to a high and honorable employment at a European Court."

101 Selected papers of John Jay, vol. I, op. cit., p. 348.

102 The writings of Thomas Paine, volume I, The knickerbocker press, New York-London, 1894; el primer volumen se encuentra en las p. 170-179 
este importantísimo documento redactado por Jay pueden extraerse las siguientes notas distintivas:

1.- Apelación a Dios no sólo como autoridad suprema ante la cual todos los seres humanos habrán de responder ("Supreme Ruler of all events, to whom every individual must one day answer for the part he now acts"), sino como fuente ultima de los derechos fundamentales que todo ser humano posee y por los cuales esta luchando la población colonial ("You and all men were created free, and authorized to establish civil government for the preservation of your rights against opresion, and the security of that freedom which God has given you against the rapacious hand of tyranny and lawless power"). De ahi que esa lucha por las libertades otorgadas por Dios sea un deber, y que en última instancia, la causa americana se encomiende a la propia divinidad ("bound by the strongest obligations to defend the inheritance which God has given to us, to him we referred our cause").

2.- Efectúa un repaso de los acontecimientos históricos que han conducido a la situación bélica, es decir, a las vulneraciones de los derechos perpetradas por Gran Bretaña, por lo cual considera una obligación alzarse contra quienes abusen (el significativo término utilizado por Jay es "prostitute") de las potestades públicas con la finalidad de vulnerar derechos y libertades. Con todo, si la situación norteamericana es particularmente dolorosa ello se debe a la condición de los opresores, personas con quienes no sólo les unían vínculos afectivos, sino que junto a ellos habian luchado hombro con hombro y precisamente gracias al sacrificio de los colonos el Gran Bretaña habia llegado a ser lo que era ("Our enemies [...] call themselves Christians. They are a nation and people bound to us by the strongest ties. A people by whose side we have fought and bled, whose power we have contributed to raise, who owe mucho of their wealth to our industry..").

3.- Apunta al objetivo último de Gran Bretaña con sus medidas: reducir a las colonias a la esclavitud, y no a la simple obediencia. Es precisamente en este párrafo donde Jay se deja llevar por la pasión, sobre todo en las palabras finales, donde rechaza enérgicamente los deseos de algunos para finalizar el conflicto ("Obedience? To what? To their sovereign, will and pleasure. And what then? Why then you shall be pardoned, because you consent to be slaves. And why should you be slaves now, having been freemen ever since this country was settled? Because, forsooth the King and Parliament of an island, three thousand miles off, chuse that you should be hewers of wood and drawers of water for them. And is this people whose proud domination you are taught to solicit? Is this de peace which some of you so ardently desire? For shame! For shame!"). Las promesas de clemencia del monarca inglés son, para Jay, un engaño cuyo objetivo último no es otro que debilitar a los colonos sembrando la desunión ("The truth is, peace is not meant, and their specipus pretences and proclamations are calculated only to disunite and deceived.").

4.- A la hora de analizar las derrotas militares, Jay intenta levantar los ánimos de la población acudiendo a elementos tanto puramente técnicos como religiosos, si bien es cierto que prima los últimos sobre los primeros. Es cierto que se refiere a la superioridad y disciplina de los ejércitos británicos frente a la 
bisoñez y los escasos medios de las milicias coloniales, pero esa superioridad del enemigo no puede prevalecer contra Dios ("God himself hath told us that strength and numbers avail not against him"). La explicación de las derrotas militares no implica que la causa americana no sea la causa divina, sino que la explica, al igual que la conquista de Jerusalen por las tropas babilónicas, a modo de un desvío temporal de la divinidad por el comportamiento pecador de los americanos; por ello, al ser ese desvío temporal y al ser Dios clemente y misericordioso (no como el monarca inglés), los remedios para la adversidad son simples: volver de nuevo a la rectitud y al camino de Dios ("The king of heaven is not like the King of Britain, implacable. If is assistance be sincerely implored, it will surely be obtained. If we turn fromour sins, he will turn for his angers").

5.- Es en los últimos párrafos donde el redactor de este importantísimo documento pone toda la carne en el asador para alzar los ánimos de sus compatriotas. En primer lugar, enuncia la idea clave: no se está luchando por la mera conservación o conquista de territorios, sino por la libertad y la felicidad no sólo de los colonos, sino por la de quienes aún están por nacer ("we do not fight for a few acres of land, but for the Freedom; for the freedom and happiness of millions yet unborn"). Y finaliza con una patriótica arenga donde invoca de nuevo a su principal aliado, que no es otro que la propia divinidad ("Rouse therefore, brave Citizens. Do your duty like men. And be persuaded that Divine Providence will not permit this western world to be involved in the horrors of slavery")

\subsection{La primera Constitución del estado de Nueva York, aprobada el 20 de abril de 1777.}

Desde febrero de 1777, y en la medida que el devenir de los acontecimientos militares lo permitieron, las tareas de Jay se concentran en la redacción del proyecto de Constitución del estado de Nueva York. En este punto va a producirse un nuevo enfrentamiento entre moderados y radicales, lucha que se va a solventar de una manera paradógica: si bien las tesis moderadas van a triunfar en lo que se refiere a la articulación constitucional, los radicales van a lograr el control de las instituciones durante un periodo nada desdeñable que se prolongará más de una década.

Un buen resumen del proceso constituyente que finalizó en 1777 lo ofrece el relato de un anónimo autor encubierto con el seudónimo "Schuyler", para lo cual se sirvió de fuentes de primera mano. La importancia del texto fue tal que el mismo fue incluido a modo de apéndice en las actas de la Asamblea Constituyente de 1821 que tuvo por objeto reformar el mismo, ${ }^{103}$ pues, como se indica: "These memoranda may be relied on as authentic; and are deemed to be of sufficient interest, to entitle them to a place in the appendix to this volumen."

El mismo día 10 de julio de 1776 se acordó iniciar la construcción jurídica del nuevo estado mediante la aprobación del texto constitucional, y el día 1 de

103 Nathaniel H. CARTER y William L STONE, Reports of the proceedings and debates of the Convention of 1821 assembled for the purpose of amending the Constitution of the State of New York, containing all the oficial documents relating to the subject, and other valuable matter, E. and E. Hosford, Albany, 1821. El apéndice con el resumen del proceso constituyente de 1777 obra en las páginas 691 y siguientes. 
agosto de 1776 se nombró un Comité de trece miembros, entre los cuales se encontraba John Jay, cuyo objetivo no era otro que "prepare and report a constitution or form of government". No obstante, la invasión del territorio por las tropas británicas demoró el inicio del proceso constituyente al priorizar la defensa militar del estado sobre cualquier otro asunto, lo que ocasionó que el meritado comité no iniciase sus trabajos hasta bien entrado el mes de febrero del año siguiente. $\mathrm{Y}$ lo cierto es que, en el momento de iniciarse los trabajos constituyentes, se va a producir un enfrentamiento entre los radicales y los moderados. Los radicales eran partidarios del sufragio universal, atribuir el poder legislativo una Asamblea unicameral que se constituyese en el auténtico nervio del Estado y depositar el poder ejecutivo en un Gobernador con poderes limitados. Los moderados, por contra, defendian el sufragio censitario, un legislativo bicameral y un Gobernador con amplias prerrogativas. Jay se encontraba indubitadamente entre los conservadores, y en este punto quizá influyó en no poca medida el fuerte recelo hacia el elemento popular que le acompañó desde su época estudiantil, y que era compartida por algunos de sus colegas. Baste para ello comprobar las reflexiones que Edward Rutledge le dirigía en carta fechada el 24 de noviembre de 1776 y en la que justificaba las razones que, a su entender, avalarian la necesidad de poner límites al elemento popular: "your country I think will be safe provided you establish a food Government with a strong Executive - a pure Democracy may possibly do when patriotism is the ruling passion, but when a state abound in Rascals (as is the case with too many at this day) you must supress a little of that popular Spirit, vest the executive powers of Government in an individual that they may have Vigor \& let them be as ample as is consisten with the great outlines of Freedom."104

Durante el mes de febrero, Jay redacta un borrador de constitución que se encontraba bastante influido por las tesis que defendiera John Adams en su opúsculo Thoughts on Government ${ }^{105}$. Aunque tradicionalmente se considera a Jay el responsable máximo del proyecto constitucional sometido a debate, entre otras cosas porque era un texto manuscrito cuya letra era indubitadamente la de Jay $^{106}$, lo cierto es que las recientes investigaciones parecen demostrar que a la hora de acometer su redacción tenía en su poder materiales previos, que habría

104 SPJJ I, 307-308.

105 El texto de este breve opúsculo puede encontrarse en The Works of John Adams, vol. IV, Charles C. Little and James Brown, Boston, 1851, p. 193-209. En dicho texto, Adams defiende la forma republicana de gobierno bajo la forma de un Estado de Derecho regido por las leyes. Aboga porque el legislativo estuviese en manos de una asamblea representativa que debía ser "in miniature an exact portrait of the people at large". Abogaba por un bicameralismo y atacaba de ferozmente la idea de un legislativo unicameral. Serian las dos cámaras legislativas quienes, de forma conjunta, elegirian al Gobernador.

106 "The committee, appointed to prepare a form of government was required to reporto $n$ the following Wenesday: and on that day (12th march, 1777) said committee reported a plan or form of government, which was read by Mr. Duane. This draft was chiefly or wholly drawn up by Mr. Jay and is in his handwritting", Nathaniel H. CARTER y William L STONE, Reports of the proceedings and debates of the Convention of 1821 assembled for the purpose of amending the Constitution of the State of New York, containing all the oficial documents relating to the subject, and other valuable matter, op. cit., p. 692. 
sistematizado y ordenado107. En principio, Jay debía sentirse bastante optimista por cuanto en carta que dirige el dia 23 de marzo de 1777 a William Livingston le indica que: "Our convention has now under consideration the report of the Committee for preparing a form of Govt. for this state. Unless my expectations are very ill founded, our Constituents will have great reason to be satisfied"108

El proyecto constitucional fue sometido a debate, en el seno del cual John Jay brilló con luz propia avalando enmiendas que en gran parte mostraban un talante abierto e incluso avanzado en muchos aspectos (avaló la supresión de la esclavitud, aunque en este punto concreto no prosperó), no obstante lo cual en un aspecto hizo gala de una intolerancia extrema: en su defensa a ultranza de las restricciones que a su juicio debería imponerse a quienes profesasen la religión católica $^{109}$. Jay no sólo era una persona religiosa por tradición familiar, sino por convicción auténtica, y a lo largo de su vida mantuvo incólume una profunda fe que se reveló en alguna que otra significativa anécdota; no obstante, su fe era de raíz protestante, y no podía olvidar que sus ancestros se vieron obligados a abandonar Francia por la persecución a que fueron sometidos en nombre del catolicismo, y de ahí que su intervención en los debates constitucionales en lo que al catolicismo se refiere se mostró en extremo tajante.

Otro extremo que Jay deseó incorporar al texto constitucional de Nueva York fue la proscripción de la esclavitud. No obstante, no pudo defender dicha enmienda debido a un luctuoso suceso: el fallecimiento de su madre el día 17 de abril, tres días antes de la aprobación final de la Constitución. La enmienda abolicionista fue presentada por Gouverneur Morris, pero no logra prosperar, y para Frank Monaghan fue quizá la ausencia física de Jay el hecho decisivo para que la proscripción de la esclavitud fuese derrotada ${ }^{110}$. Tres días después, el texto constitucional fue definitivamente aprobado sin variaciones relevantes en cuanto al fondo.

La primera Constitución del estado de Nueva York es finalmente aprobada el 20 de abril de 1777111, y según Frank Monaghan, "despite its defects, some of which Jay remarjed and other which later became aparent, it was the best of the various state constitutions until Massachussets framed her plan of government in

107 Todo este proceso de redacción aparece perfectamente resumido en la breve introducción que se efectúa a los documentos relativos a la elaboración del texto constitucional neoyorkino en Richard B. MORRIS, John Jay: The making of a revolutionary, op. cit., p. 389-394, introducción que se reproduce literalmente en SPJJ, I, 399-406.

108 SPJJ, I, 389. Es significativo que Jay tachase la palabra "people" y la sustituyese por "constituents"

109 "In many ways, Jay showed himself during the constitutional debate, to be a progressive thinker. He proposed, and the Convention adopted, a provision protecting indians against fraudulent contracts. He also supported a proposal by Gouverneur Morris, not adopted by the Convention, to abolish slavery over time. In one important respect, however, Jay showed himself a reactionary. Perhaps reflecting views of his father, Jay was the proponent of several anti-catholic amendments", Walter STARR, John Jay, founding father, op. cit., p. 93.

110 Frank MONAGHAN, John Jay, defender of liberty, op. cit., p. 95-96

111 El texto constitucional puede consultarse en The Constitution of the State of New York, Philadelphia, Styner and Cist, 1777. 
$1780^{\prime 112}$. Es un texto en cuya redacción late un compromiso o intento de transacción o acercamiento entre las posturas de los radicales y de los moderados, y es precisamente este aspecto, el carácter conciliador del documento constitucional, en el que incide Robert Troup en carta dirigida a Jay el 15 de mayo de 1777 cuando le informa que: "The General [se refiere a Horatio Gates, a cuyas órdenes servia Troup] has read your Constitution with Care and Attention. He really venerates it, and thinks it preserves a proper Line between Aristocracy on the one Hand, and Democracy on the other." Se trata de una Constitucion relativamente extensa en la cual pueden distinguirse dos partes claramente diferenciadas. La primera, una justificación o exposición de motivos limitada a un brevísimo párrafo justificativo de las razones que amparan la creación del nuevo estado ("the many tyrannical and oppressive usurpations of the King and Parliament of Great Britain on the rights and liberties of the people of the Amreican colonies had reduced them to the necessity of introducing a government by congresses and committees, as temporary expedients, and to exist no longer than the grievances of the people should remain without redress") después del cual se transcriben literalmente la resolución adoptada el 31 de mayo de 1776 por el Congreso colonial de Nueva York y la Declaración de Independencia aprobada en Philadelphia el 4 de julio de 1776. La segunda, integrada casi en su totalidad por lo que en terminologia jurídica moderna se denomina parte orgánica del texto constitucional, aunque en alguno de los preceptos finales se contienen preceptos destinados a garantizar determinados derechos fundamentales. De la misma, pueden estraerse las siguientes notas o características:

1.- Se inspira claramente en el principio de soberanía popular, en cuanto emana directamente del "good people of this State". El principio se lleva incluso de forma forma explícita a su articulado, en concreto en el primero de los artículos, según el cual el texto constitucional se adopta "in the name and by the authority of the good people of this State" precisando que "no authority shall, on any presence whatever, ve exercised over the people or members of this State but such as shall ve derived from and granted by them". De igual forma, los artículos segundo y decimoséptimo, al atribuir las potestades legislativa y ejecutiva, utilizan la misma fórmula expositiva para indicar la fuente máxima o titular último de la soberanía: "the good people of this state." No obstante, no se contemplaba un sufragio universal, sino censitario, pues el artículo séptimo no sólo exige para la votación un periodo mínimo de residencia en cualquiera de los condados en que se dividia el estado de Nueva York (en realidad más simbólico que otra cosa, pues el periodo se fijaba en "six months inmediately preceding the day of the election") sino unas cualidades personales y de capacidad económica determinados ("he shall have been a freeholder, possessing a freehold of the value of twenty pounds, within the said county, or have rented a tenement therein of the yearly value of forty shillings, and been rated an actually paid taxes to this State"). Incluso el articulo octavo contemplaba la posibilidad de que, con carácter previo a ejercer el derecho al voto, se exigiese juramento de lealtad al estado, o simple promesa en el caso de los cuáqueros. No obstante, sí que se contemplaba una garantía de los derechos fundamentales de los ciudadanos del estado: el artículo decimotercero disponía que " $n$ o member of this State shall be disfranchised, or deprived of any the rights or

112 Frank MONAGHAN, John Jay, defender of liberty, op. cit., p. 96-97. 
privileges secured to the subjects of this State by this constitutions, unless by the law of the land, or the judgment of his peers."

El trigésimo primer artículo contiene otra manifestación de la soberanía popular, al estipular que las leyes se encabezarian con la expresión "Be it enacted by the people of the State of New York, represented in senate and assembly", y las resoluciones judiciales con la formula "The people of the State of New York".

2.- A la hora de atribuir el "supreme legislative power", el artículo segundo opta por un sistema bicameral ("two separate and distinct bodies of men") a los que denomina Asamblea y Senado y a los cuales se impone constitutionalmente reunirse al menos una vez al año "for the dispatch of bussiness". El articulo decimocuarto precisaba que "neither the assembly or the senate shall have the power to adjounr themselves for any longer time tan two days, without mutual consent of both". El texto constitucional contemplaba igualmente en su decimoquinto artículo un procedimiento específico a seguir para el supuesto de conflicto o desacuerdo entre ambos cuerpos legisladores.

A.- La Asamblea estaría integrada, según el artículo cuarto, por un mínimo de setenta miembros elegidos anualmente en los distintos condados (el propio artículo desglosa el número de representantes a elegir en cada uno de los catorce condados, siendo el que más aportaba el de Albany con diez, y los que menos Kings, Richmond y Gloucester con dos cada uno). Según el artículo octavo la Asamblea elegiría su propio presidente y sería la encargada de enjuiciar a sus integrantes ("be judges of their own members").

B.- El Senado estaría integrado por veinticuatro propietarios libres ("freeholders") elegidos para un periodo de cuatro años, estableciendo para ello un sufragio censitario entre los propietarios del estado (artículo 10), constitucionalizando el procedimiento electoral a este fin que difería ligeramente del establecido para la Asamblea, pues la circunscripción electoral no sería el condado, sino que se dividiría el territorio en cuatro grandes distritos, cada uno de los cuales englobaba varios condados (artículo 12).

3.- El poder ejecutivo se deposita en el Gobernador, que se elegiria entre los "wise and descreet freeholder of this State, by ballot" por un periodo de tres años (artículo decimoséptimo). Ostentaría también la condición de comandante en jefe de la milicia y almirante de la armada, con la potestad de reunir a la Asamblea y al Senado en ocasiones extraordinarias, prorrogar sus sesiones "durante un periodo que no exceda de sesenta días al año", así como la prerrogativa de indulto salvo en casos de traición o asesinato (decimooctavo artículo). Se imponía igualmente al Gobernador deberes especiales de información al legislativo (decimonoveno artículo).

Junto al Gobernador existiría un Vicegobernador (lieutenant-governor) elegido mediante el mismo sistema establecido para aquel. Su función constitucional sería la de ser presidente nato del Senado, en el que únicamente podría emitir voto en caso de empate. El vicegobernador sustituiria al Gobernador en caso de fallecimiento, dimisión o remoción del cargo (vigésimo artículo). Como puede comprobarse, este sistema anticipa en una década la regulación constitucional del Vicepresidente de los Estados Unidos. 
Se contempla también la existencia de un treasurer, siendo de destacar que el mismo no lo nombra el Gobernador, sino el legislativo por ley (vigésimosegundo artículo) realzando enfáticamente que "he shall not be elected out of either branch of the legislature"

4.- No se proclama de forma explícita que el poder judicial reside en los Tribunales, ni se recoge imperativamente la existencia de órganos jurisdiccionales independientes, aunque los artículos vigésimoquinto y vigésimoséptimo mencionen expresamente tanto un Tribunal Supremo como tribunales del condado, cuya existencia se da por supuesta pero que se regulen su organización $\mathrm{y}$ competencias ${ }^{113}$. Por cierto, que el vigésimoquinto artículo contiene una excepción a la cláusula de incompatibilidad de los jueces: los miembros del Tribunal Supremo no podrían ostentar otro cargo mientras desempeñasen las funciones jurisdiccionales, excepto el de Delegado al Congreso general "upon special ocassions"; por el contrario, los jueces de condado tampoco podrian ostentar cargo alguno "excepting that of Senator or Delegate to the general Congress"

El vigésimo séptimo artículo abordaba el nombramiento del personal relacionado con la Administración de Justicia, que sería elegido por los titulares del órgano judicial en el que ejerciesen. De igual forma, este precepto establecía que los abogados ("attorneys, solicitors and counsellor at law") serian nombrados por el Tribunal, "and licensed by the first court in which they shall respectively plead or practise, and be regulated by the rules and orders of the said courts".

5.- Una de las principales características del texto constitucional de 1777 consiste en la existencia de dos organismos cuyo objetivo último no era otro que lograr un compromiso entre el sector radical y el conservador en cuanto a la extensión de las potestades del Gobernador. Para lograr un equilibrio entre legislativo y ejecutivo, se crearon dos órganos específicos:

A.- El denominado Council of Appointment, recogido en el vigesimotercer artículo del texto constitucional, encargado del nombramiento de los distintos cargos públicos. Se nombraría un senador procedente de cada uno de los distritos en que se dividia el territorio a efectos de las elecciones para la Cámara Alta, y ese grupo de senadores estaría presidido por el Gobernador, el Vicegobernador o el presidente pro tempore del Senado, si bien el presidente

113 Walter Starr explica con acierto dicha omision indicando que "it generally assumed that the various colonial courts would continue in the new State system."; John Jay, founding father, op. cit., p. Curiosamente esta es la misma explicación que el actual chief justice, John Roberts, ofrece a la escasa regulación del Poder Judicial en la Constitución federal de 1787: "I think it was because they had a pretty good idea in understanding what a Court was and how it function. You know, when you look arround the world today, we try to do as we can to help new democracies get established. One of the hardest things to do is to establish an independent Courts that will apply the rule of law, because they don't have a tradition for Courts doing that. We were fortunate coming from the English british model. They have courts that implemented the rule of law. We had some disagreements with how they were set up and everything but they underestood what Court apply the law fairly look like, so they didn't have to spend time talking about it"; https://www.youtube.com/watch?v=fRoNWcgzluQ (consultado el dia 12 de mayo de 2016). La respuesta transcrita se encuentran en los minutos 2:25 a 2:46. 
tendría "a casting voice, bur no vote". Este órgano colegiado sería el encargado de otorgar, por mayoría, el "advise and consent" para que el Gobernador efectuase los nombramientos de cargos públicos.

B.- El segundo órgano, creado para lograr un compromiso entre los partidarios y detractores de otorgar el poder de veto al Gobernador, es el Council of Revision, recogido en el artículo tercero del texto constitucional, e integrado por el Gobernador, el Canciller y los jueces del Tribunal Supremo del Estado, quienes no percibirían ninguna retribución adicional por ello. La misión fundamental de esta novedosa institución consistiría en asegurar no sólo que los proyectos de ley aprobados por las cámaras no fuesen "inconsistent with the spirit of this constitution or with the public good." Para ello, revisarian todos los proyectos de ley adoptados por las Cámaras, y en caso de que dicho órgano formulase reparos, los remitiría por escrito al legislativo; para el caso de que no se formulase ninguna objeción en diez dias, se entendía que se otorgaba el placet al texto. Las objeciones, no obstante, podian levantarse por el legislativo por mayoria de dos tercios. Como puede comprobarse, el Council of Revision no hacía otra cosa que ejercer la potestad de veto legislativo.

Junto a esas disposiciones orgánicas, el texto contemplaba otras cuestiones como, por ejemplo, declarar expresamente la vigencia en Nueva York tanto del statute law y el common law británico como la legislación aprobada por los órganos coloniales neoyorkinos antes del 19 de abril de 1775, si bien sujetas a "such alterations and provisions as the legislatura of this State shall, from time to time, make concerning the same" (artículo trigésimoquinto), dejando bien claro, no obstante, que no mantenian su vigencia aquéllas partes que "be construed to establish or mantain any particular denomination of Christian sor their ministers, or concern the allegiance heterofore yiended to, and the supremacy, sovereignty, government or prerogatives claimed or exercised by the King of Great Britain and his predecessors, over the colony of New York and its inhabitants, or are repugnant to this constitution", aspectos que son expresamente anulados, de igual forma que el artículo siguiente, el trigésimosexto, declaraba nulas todas las concesiones que con posterioridad al 14 de octubre de 1775 hubiese efectuado en el territorio neoyorkino el monarca inglés.

Cuando Jay consulta el texto constitucional finalmente aprobado, encontró varias objeciones, pero sobre todo le disgustó profundamente el hecho de que se hubiese modificado el nombramiento del personal de la Administración de Justicia, atribuyendo la potestad a los jueces y no al Council of Appointment. Tan es así, que Jay manifestó por escrito sus objeciones a John Sloss Hobart, el Secretario de la Comisión, puenteando a sus colegas y amigos Gouverneur Morris y Robert L Livingston. Éstos, dolidos, dirigen el 26 de abril de 1777 una carta a Jay manifestando su sorpresa no sólo porque "neither had we the most distant Idea that a clause of this sort cound meet with yoru dissaprobation since you was so fully of opinion to appoint by judges of the supreme court not only clerks but all other civil officers in Government", sino por las consecuencias que ello podría tener para el futuro del texto constitucional dado el prestigio y fama del que Jay gozaba ya en esos momentos: "Judge then our amazement at reading a letter from $\mathrm{Mr}$ McKeeson to his Fellow Secretary in which your sentiments against the power vested in the courts are blazoned in glowing colours and consider how far your 
reputation may or may not tontribute to make this Constitution a living lae or a dead letter accordin to the scale in which you shall choose to place it." Esta carta obtiene respuesta en otra larga misiva fechada tres dias más tarde en la que Jay defiende su tesis y su actuación poniendo de manifiesto los riesgos que, a su entender, supondria atribuir la potestad del nombramiento a los jueces: "That cklerks should be dependent is agreed on al hands. On whom? Is the only question. I think not on the judges because the chancellor and the judges of the Supreme Court holding permanent commissions will be tempted not only to give this appointments to their children brothers relatives and favorites, but to continue them in office against the public Good. [...] besides, men who appoint others to offices, generally have a partiality for them, and are often disposed on principles of pride as well as interest, to support them. By the clerks of courts being dependent on the judges collusion becomes more easy to be practiced, and more difficult to be detected, and instead of publishing and punishing each other transgressions, will combine in concealing palliating or exclusing their mutual defects or misdemeanors." Por cierto, que en esa misiva Jay incide en un hecho que aún hoy es inherente a la abogacía americana y, desgraciadamente, ajena al mundo jurídico español, cual es la naturaleza de los abogados: "an attorney is an officer of a common law court". Por ello, y porque los abogados han de ejercer no sólo en un tribunal, sino en varios, no puede depositarse en éstos la potestad de nombramiento, porque ello traería nefastas consecuencias, que incluso profetiza en un párrafo entre jocoso e iracundo: "Remember that I now predict, that this same clause which thus give inferiour Courts uncontrouled and unlimited authority to admit as many attorneys as they please, will fill every county in the state with a swarm of designing cheating litigious pettifoggers, who like leaches and spiders will fatten on the spoils of the poor the ignorant the feeble and the unwary."

\subsection{Chief justice de Nueva York y renuncia a ser candidato a Gobernador. Nueva elección como delegado al Congreso Continental.}

Al igual que ocurriria en España durante la guerra de la independencia que tendria lugar tres décadas más tarde, en Nueva York durante estos años existieron dos regimenes jurídicos distintos, pues si en las zonas ocupadas militarmente por las tropas británicas permanecian las antiguas instituciones coloniales, en los territorios bajo poder de las milicias coloniales empezó a regir el texto constitucional de 1777.

El 3 de mayo de 1777 se nombra un Council of Safety, que se encargaría de ejercer los poderes hasta que se celebraran las elecciones para elegir las Cámaras y al Gobernador. Ese mismo dia 3 de mayo de 1777 John Jay es nombrado Chief Justice of the Supreme Court of Judicature o, por utilizar sus propias palabras en carta dirigida a Richard Morris el dia 10 de mayo de 1777, "the first place on the Bench." No obstante, su nombre comenzó a sonar reiteradamente para ocupar el cargo de Gobernador del estado, por lo Jay se vio precisado a despejar toda duda al respecto llegando a manifestar explicitamente hasta en tres ocasiones que no ocuparia dicho puesto, pues aun cuando intimamente consideraba dicho puesto no sólo económica sino políticamente mucho más atractivo, en tan difíciles momentos Jay se consideraba más util en la judicatura. La primera, en carta dirigida el 16 de mayo de 1777 a Abraham Yates jr, donde no sólo le expone los 
motivos indicados, sino que le insta de forma expresa a que no se utilice su nombre como candidato a la Gobernacion: "That the office of first Magistrate of this State will be more respectable as well as more lucrative and consequently more desirable than the Place I now fill, is very apparent. Bur Sir! My object in the Cours of the present Freat Contest neither has been nor will be either rank or money. I am persuaded that I can be more useful to the State in the office I now hold than in the one alluded to, and therefore think it my duty to continue in it. You are acquainted with the Reasons which induce me to be of this opinion, and altho I entertain a high Sense of the Honor which my Friends are disposed to confer upon me, I must request the Favor of them not to encourage my being name as a Candidate for that Office, but to endavour to unite the Vores of the Electors in that Cointy of Albany in favor of some other Gentleman"114. A principios de junio reitera esa misma idea en dos epístolas, las que dirige el 5 de junio a Leonard Gasnsevoort y el 6 de junio a John Ten Broeck, rogando que en el condado de Albany su nombre no se utilice como un potencial candidato a la gobernación del estado115. Jay apoyó la candidatura de Philiph Schuyler, y pese a gozar de un amplio apoyo, fue derrotado por George Clinton, quien en esos momento se encontraba en el frente de batalla. Clinton, simpatizante del ala revolucionaria y futuro líder de la facción republicana liderada por Jefferson, supo contemplar el cambio de rumbo en la politica pues, como indica Walter Starr, "Schuyler and Jay were still working in an old style of politics, relying on family and connections. Clinton was developing a new style of politics, relying on rapport tith the common people."116 George Clinton permanecería como Gobernador del estado de Nueva York hasta el 30 junio de 1795, año en el que curiosamente fue John Jay, quien en esos momentos ocupaba la Presidencia del Tribunal Supremo de los Estados Unidos, quien le sucedió en el cargo. Jay finalizaría su larga carrera política en 1801, tras dos mandatos como Gobernador de su estado natal.

En su condición de chief justice, Jay inauguró las sesiones del órgano judicial el día 9 de septiembre de 1777 en Kingston, donde aprovechó la oportunidad de digirirse al jurado del condado de Ulster para hacer una serie de reflexiones de carácter no estrictamente jurídico, sino político-constitucional. Comenzaba felicitando a los integrantes del mismo "on the dawn of that free, mild and equal government which now begins to rise and break from amid those clouds of anarchy, confusion and licentiousness which the arbitrary and violent domination

114 SPJJ I, 419. El salario del Gobernador ascendía a 1.000 dólares, mientras que el del Canciller, el Chief Justice y el Treasurer se reducía a menos de un tercio de dicha cantidad, 300 euros, según carta que el 3 de junio de 1778 dirigió Jay a Gouverneur Morris.

115 En la primera de las cartas, indicaba que "In my opinión, I can be more useful in place I now hold; and therefore, tho the other is far more respectable as well as lucrative, yet Sir! The regard due to the public Good induces me to decline this pomotion. I thought it necessary that you \& others should be informed of my Sentiments on this subject \& it would give me Pleasure to hear that the Electors in Albany had united in a design of voting for one Gentleman whose Spirit abilities and reputation might recommend him to that important office"; en la segunda, reiteraba esa misma idea: "Having understood that I was named as one of the candidates for the office of Governor, by some of my friends in Albany; and being desirous that as much unanimity as possible should prevail on this ocassion, I take the liberty of informing you, that in my opinion it will be most for the common good that I should remain in the office I now hold"; SPJJ, I, 433 y 435.

116 Walter STARR, John Jay, founding father, op. cit., p. 96. 
of Great Britain had spread in greater or less degree throughout this and the other American States." El mismo se manifiesta en términos muy duros contra los actuales gobernantes de Gran Bretaña, y, al igual que el resto de escritos de Jay, contiene numerosas invocaciones a la autoridad divina. Pero ya en este primer aserto al jurado neoyorkino apunta Jay una idea que a partir de entonces se fijará sólidamente en su pensamiento: pese a la diversidad territorial e institucional de las colonias, sus habitantes constituyen un único pueblo que lucha unido por su libertad, y lo hace en un párrafo en el que sin duda alguna Jay pone toda su alma y que sintetiza de forma magistral su pensamiento: "Will it not appear extraordinary that thirteen colonies, the object of their wicked designs, divided by variety of governments and manners, should inmediately become one people, and though without funds, without magazines, without disciplined troops, in de thace of their enemies, unanimously determine to be free, and undaunted by the power of Britain, refer their cause to the justice of the Almighty, and resolve to repel force by force, thereb presenting to the world an illustrious example of magnanimity and virtue scarcely to be paraleled?" De hecho, llega a dar las gracias a Dios porque ha convertido al pueblo americano en poco menos que en el elegido, dado que es el primero en otorgarse sus propios instrumentos de autogobierno: "The Americans are the first people whom Heaven has favoured with an opportunity of deliberating upon, and choosing the forms of government under which they should live. All other constitutions have derived their existence from violence or accidental circunstamces..." Jay incide en esta circunstancia, en que a partir de ese momento todo está en manos de Dios y del pueblo, por ese orden: "Your lives, your liberties, your property, will be at the disposal only of your Creator and yourselves." A continuación efectúa una proclama de libertad religiosa y de conciencia, defendiendo el derecho de cada individuo a adorar a Dios a su manera. En los últimos párrafos ya introduce las advertencias propias que un juez dirige a los miembros de un jurado: "I presume it will be unnecesary to remind you, that neither fera, favour, resentment, or other personal and partial considerations, should influence your conduct. Calm deliberate reason, candour, moderation, a dispassionate and yet a determined resolution to do your duty, will, I am persuaded, be the principles by which you will be directed."117

John Jay presidiria las sesiones del Supreme Court of Judicature los meses de abril y agosto de 1778. No obstante, poca información existe acerca de este corto periodo en el que Jay estuvo al frente de la judicatura estatal neoyorkina, puesto que "The authority of the Court extended only over those regions of the State held by patriots; the richest and most populous districts were still in the jurisdictions of the Supreme Court of the province. During the revolution, the State Supreme Court never sat en banc and there are no published reports of its decisions." 118 No obstante, el propio Jay ofrece algún apunte concreto no sólo de sus principales funciones judiciales, sino del ambiente social que se respiraba en la parte del estado controlada por los milicianos rebeldes. Así, en una carta dirigida el día 29 de abril de 1778 a Gouverneur Morris, reconocia estar "engaged in the most disagreable part of my Duty -trying Crominals. They multiply exceedingly.

$117 \mathrm{El}$ texto integro de esta importantísima pieza en SPJJ, I, 477-481.

118 Frank MONAGHAN, John Jay, defender of liberty, op. cit., p. 101. 
Robberies become frequent. The woods aford them Shelter \& the Tories food. Punishments must of Course become certain \& Mercy dormant - a hars system repugnant to my feelings, but nevertheless necessary. In such Circumstances Lenity would be Cruelty \& Severity is found on the Side of Humanity"119

Al ostentar la condición de chief justice, Jay era miembro nato del Council of Revision, que, recordemos, era el órgano encargado de revisar la constitucionalidad de los proyectos de ley con anterioridad a su entrada en vigor. Durante el periodo comprendido entre septiembre de 1777 y noviembre de 1778, dicho órgano vetó seis proyectos legislativos, y en cinco ocasiones a instancias de Jay. Destaca sobremanera la oposición a un proyecto tendente a privar del derecho de voto a los ciudadanos que, con posterioridad a aprobarse la Declaración de Independencia, hubiesen permanecido leales al monarca inglés; Jay defendió que se trataba de un precepto inconstitucional al prever la irretroactividad de una disposición restrictiva, contraria además al texto constitucional en cuanto que éste preveía la posibilidad de que se permitiese el voto si en el momento de celebrarse los comicios, el ciudadano hubiese prestado juramento de lealtad al estado ${ }^{120}$.

Aunque Jay permaneció formalmente como chief justice hasta el mes de agosto de 1779 , lo cierto es que su designación en noviembre de 1778 como representante del estado de Nueva York en el Congreso Continental hizo que de facto sus actividades en el empire state cesasen al dedicarse a sus responsabilidades en el órgano supraestatal. De hecho, en octubre de 1778 es Robert Yates el juez del Supreme Court of Judicature quien suple la ausencia del chief justice. No fue sino hasta nueve meses después cuando Jay decidió poner fin a esa situación, y el 18 de agosto de 1779, en carta dirigida al Gobernador Clinton y al Council of Appointment, comunicaba su renuncia a su cargo de juez. Ese mismo día 18 de agosto dirigía una carta a George Clinton informándole de que había remitido su carta de dimisión al Canciller, aunque le rogaba "say nothing of it till you see him"; indicaba igualmente su deseo de "return to private life", aunque estaba dispuesto a regresar de nuevo "whenever my country shall call me from it". Sin duda alguna, a Jay debieron llegarle peticiones de que reconsiderase su postura, dado que un mes más tarde, el 16 de septiembre de 1779, dirige una carta al Gobernador Clinton reafirmándose en su dimisión e indicando de forma inequivoca la firmeza de la misma: "My resolution to resign Office of Chief Justice was taken after much Deliberation and Thought on the Subject. I have since frequently examined the Reasons which influence me to that Measure, and Still remain perfectly satisfied with them, and there is therefore no probability of a Change in my opinion, and therefore it will be unnecesary to detain my resignation any longer from the Council of Appointment."

119 SPJJ I, 514. Según Walter Starr, "In fact, however, in appropriate circumstances, he would show mercy. At the end of the Albany sesion, Jay and the other judges sentenced eleven men to death for varous offenses, including murder and horse theft; they also recommended, in a report drafted by Jay, that Governor Clinton pardon three of these men"; John Jay, founding father, op. cit., p. 101.

120 Walter STARR, John Jay, founding father, op. cit., p. 102; Frank MONAGHAN, John Jay, defender of liberty, op. cit., p. 101-102. 
Jay ponía fin así a un trienio dedicado en cuerpo y alma a la articulación jurídica del estado de Nueva York, y su renuncia vino a coincidir con su propia salida del territorio americano para desplazarse como plenipotenciario norteamericano nada menos que a la corte del rey Carlos III de España. No obstante, durante casi diez meses, Jay ocupó nada menos que la presidencia del máximo organismo que en aquellos años tenía en sus manos los poderes de los Estados Unidos: el Congreso Continental.

\section{PRESIDENTE DEL CONGRESO CONTINENTAL (1778-1779).}

\subsection{Elección como Presidente del Congreso Continental.}

Como indica Walter Starr, si una disputa territorial entre dos colonias marcó el inicio profesional de Jay como abogado ejerciente, otra disputa territorial va a lanzarle de nuevo a la política supraestatal en lo que va a suponer el final de la primera etapa en la vida pública de Jay en territorio norteamericano. En efecto, una serie de conflictos territoriales entre las colonias de New Hamphsire y Nueva York, territorios cuyos colonos acabarian por declarar independientes constituyendo el estado de Vermont, hicieron que las disputas acabaran en el Congreso Continental. Para ello, Nueva York decidió que debía enviarse a dicho órgano a una persona de acreditada solvencia jurídica que, a la vez, gozase de unas sólidas credenciales politicas. Por ello, el 4 de noviembre de 1778 el legislativo neoyorkino interpretó que esta era una de las "special ocasions" en las cuales el artículo XXV del texto constitucional permitía compatibilizar el cargo de juez del Tribunal Supremo del Estado con el de delegado al Congreso Continental, y elige a John Jay para que regresase nuevamente a Filadelfia como representante del estado de Nueva York. Tras dos años de ausencia, Jay regresaba al organismo que había sido su plataforma de lanzamiento a la política nacional. Y ello pese a que en una carta dirigida en agosto de dicho año a Governeur Morris, auguraba que "it will probably be long before the duties of my office will permit me to leave this state." $121 \mathrm{Su}$ estancia en Filadelfia y la asunción de su nuevo cargo no supuso en modo alguno que olvidase el devenir político institucional de Nueva York, pues de la correspondencia con el propio Gobernador no sólo se demuestra que estaba al tanto de la evolución política de su estado natal, sino que incluso se permitía ofrecer por escrito su opinión a la máxima autoridad ejecutiva del empire state sobre cuestiones legislativas, como el proyecto de ley que regulaba la organización del Council of Revision ${ }^{122}$.

La incorporación de Jay y la presentación de sus credenciales al Congreso tiene lugar el dia 7 de diciembre de $1778^{123}$. Y lo hace en medio de una acendrada batalla política o, por utilizar la expresión utilizada por Frank Monaghan, el "flourishing spirit of party and cabal". Ese conflicto o rivalidad entre dos clanes es, paradójicamente, el que va a demorar la resolución del conflicto

\footnotetext{
121 SPJJ, I, 541
}

122 Cartas de George Clinton a John Jay fechada el 2 de febrero de 1779 y la contestación de éste el día 19 del mismo mes y año, en SPJJ I, 582-83 y 594-95.

123 JCC XII 1195. 
entre Nueva York y Vermont, para el que Jay había sido elegido. Esa rivalidad entre clanes se originó a consecuencia de la ayuda prestada por Francia a las colonias americanas.

En 1776, una vez aprobada la declaración de independencia, Silas Deane, fue enviado a Francia para negociar un tratado con dicho reino y obtener ayuda, lo que hzo a través de Caron de Beaumarchais. Ambos canalizaron la ayuda francesa obtenida con carácter previo a la ratificación formal de un acuerdo, a través de una entidad privada. Richard Henry Lee, enemigo político de Deane, promueve en 1778 una investigación formal que verifique el destino de las ayudas obtenidas. El asunto llega al Congreso Continental, que en la sesión del sábado 15 de agosto de 1778 acuerda que Silas Deane ofrezca una rendición de cuentas general de las transacciones efectuadas en Francia, "from the time of his arrivl, as well as a particular state of the funds of Congress, and the comercial transactions in Europe, especially with Mr. Beaumarchais, and to answer such questions as may be asked"124. El lunes 16 y el viernes 21 de agosto, Deane ofrece las explicaciones. No obstante, la situación era tan delicada que Gouverneur Morris, en carta dirigida a Jay el 16 de agosto, indicaba que "Your friend Deane, who hath rendered the most esential services, stands as one accused. The storm increases and I think some of the tall trees must be torn up by the roots." 125

E1 5 de diciembre de 1778, Silas Deane opta por hacer una defensa general de su actuación haciendo público su escrito To the free and virtuous citizens of America, un explícito ataque contra su acusador Richard Henry Lee que aprovechó para imputar a la máxima institución confederal una negligencia y desconocimiento general de los asuntos internacionales. Henry Laurens, Presidente del Congreso Continental y partidario abierto de Lee, presenta su dimisión por entender que el Congreso ha sido excesivamente timorato a la hora de responder a las acusaciones vertidas por Deane. ${ }^{126}$ Al día siguiente, jueves 10 de diciembre de 1778, John Jay es elegido nuevo Presidente del Congreso Continental.

Como dato curioso, en este punto John Jay asumió expresamente una postura abiertamente favorable a Deane, mientras que su hermano, Sir James Jay, se inclinó por el bando de los Lee.

\subsection{Sistema institucional de los Estados Unidos en 1779.}

En pleno conflicto armado con Gran Bretaña, las trece colonias pretendieron dotarse jurídicamente de un entramado institucional que les permitiera ofrecer

124 JCC, XI, 801.

125 SPJJ, I, 531

126 Según consta en el diario de sesiones del miércoles día 9 de diciembre de 1779, "the President took the chair, but before any business was entere don he arose, and having assigned sundry reasons why he could not continue longer to exegute the office of President, he resigned and inmediately quitted the Chair"; a continuación se transcribe su extensa carta de dimisión, que justifica en el hecho de no ser acusado de parcialidad en la batalla que los partidarios de Deane y de Lee estaban librando, detallando a continuación una extensa relación de su conducta a modo de descargo. 
una acción coordinada frente al enemigo exterior. Así, el 15 de noviembre de 1777 aprobaron los denominados Articles of Confederation and Perpetual Union. No obstante, la ratificación del mismo por las trece antiguas colonias se demoró durante algo más de tres años. Bien es cierto que en abril de 1778, es decir, a los cinco meses de su aprobación diez de los estados habían ratificado dicho instrumento ${ }^{127}$. E1 19 de noviembre de 1778 Nueva Jersey ratifica los Artículos y, ya bajo la presidencia de Jay, el 1 de febrero de 1779 lo hace Delaware. Maryland, la última de las trece colonias convertidas en estados, demoró la ratificación hasta el día 2 de febrero de 1781, que llegaría al Congreso el día 1 de marzo, por lo que ese día se publica oficialmente el texto definitivo de los Artículos, consignando expresamente los miembros de la delegación de cada estado encargados de manifestar la prestación del consentimiento ${ }^{128}$.

Como indica su articulado, el texto no tiene por objeto crear una nueva entidad cuasiestatal superpuesa a los trece estados que los suscriben, sino una mera unión de Estados, una Confederación en la cual, según su artículo dos, "Each state retains its sovereignty, freedom, and independence, and every power, jurisdiction, and right, which is not by this Confederation expressly delegated to the United States, in Congress assembled."; precisamente para enfatizar que no se trataba de un nuevo ente, sino de una unión de estados soberanos, el artículo uno denominaba a tal agregado "United States of America." El objetivo de la unión confederal, y en virtud de la cual los estados entran en "a firm league of friendship with each other" es garantizar la defensa común, seguridad de sus libertades y su mutuo y general bienestar, obligándose a la mutua defensa y asistencia contra cualquier ataque realizado a todos o a algunos de los Estados. No obstante, esa unión y amistad perpetua no pretende articularse únicamente ad extra, sino también ad intra, puesto que el artículo cuarto consagra la libertad de circulación y residencia entre los ciudadanos de los distintos estados, asi como la igualdad de trato (precisando expresamente que se encuentran excluidos de tales derechos los "pobres, vagabundos y fugitivos". De igual manera, en caso de que una persona convicta en un Estado huyese y se refugiase en otro de los confederados, éste estaba obligado a entregarlo si aquél le requiere para ello.

En cuanto al aspecto institucional, el único órgano previsto en el documento era el Congreso. Dicho órgano estaría integrado por representantes que los Estados elegirian por el mismo procedimiento que el utilizado para elegir su legislatura, reservándose el estado el derecho a revocar a todos o alguno de los delegados. El número de representantes por Estado no sería inferior a dos ni superior a siete, de igual forma que ningún delegado podía permanecer en el cargo por más de tres años en el término de seis años. Se establecía de igual forma una incompatibilidad absoluta entre el cargo de delegado al Congreso y

127 El primer estado en otorgar su aval a los artículos fue Virginia, que lo hizo el 16 de diciembre de 1777. En febrero de 1778 se incorporaron Carolina del Sur (el día 5), Nueva York (el día 6), Rhode Island (el día 9), Connecticut (el día 12) y Georgia (el día 26). En marzo de 1778 ratifican el texto New Hampshire (el dia 4), Pennsylvania (el día 5) y Massachussets (el día 10) y el 10 de abril se incorpora Carolina del Norte.

128 JCC XIX, 214-223. En el caso de New Hampshire, New Jersey, Pennsylvania, Delaware, Maryland, Carolina del Norte y Georgia aparece consignada la fecha que no es coincidente con la de la ratificación, sino con la de llegada de ésta al Congreso. 
cualquier puesto de los Estados Unidos. El Congreso se reuniría todos los años el primer lunes del mes de noviembre (artículo 5), aunque ulteriormente establecía que podría reunirse en cualquier momento del año y en cualquier lugar de los Estados Unidos y el periodo de sus sesiones no durará más de seis meses, publicándose mensualmente el Diario de sus actuaciones (artículo 9). En el Congreso, cada Estado tendría un voto. No hallándose reunido el Congreso, el Comité de los Estados o nueve de sus miembros están autorizados para ejecutar aquéllos poderes del Congreso que le otorgue mediante el consentimiento de nueve estados.

El artículo 13 reguaba el procedimiento de reforma, al estipular que el texto de los Artículos no sería alterado, "unless such alteration be agreed to in a congress of the United States and be afterwards confirmed by the legislatures of every state".

La organización institucional que los Artículos de la Confederación establecian llevaba en sí, sin pretenderlo, el gérmen de su futura crisis. En este sentido, Richard Beeman, en el capitulo inicial de su reciente ensayo dedicado al proceso constituyente de 1787, destaca tres aspectos que eran un foco potencial de conflictos: el Congreso continental (único órgano previsto) carecía de potestad tributaria, por lo que en lo que a ingresos económicos se refiere la Confederación dependía en exclusiva de las aportaciones voluntarias de los estados; precisaba la unanimidad de las legislaturas estatales para cualquier modificación de los Artículos; y, por último, carecía de un órgano ejecutivo capaz de llevar a efecto con energía la dirección de la política ${ }^{129}$.

En cuanto a la Presidencia del Congreso Continental, se trataba de un cargo que indudablemente ofrecía a su titular una aureola de auctoritas más que de potestas, pese a lo cual se consideraba el puesto como "the first office in the Continent"130. Porque lo cierto es que la Presidencia no tenía ninguna otra facultad que la de dirección de los debates ${ }^{131}$. Este sería el puesto que ostentaría Jay durante nueve los nueve meses que transcurren entre diciembre de 1778 y septiembre de 1779 .

\subsection{Labor de Jay como Presidente del Congreso.}

Apenas elegido Presidente del Congreso Continental, Jay se ve inmerso de lleno en la polémica que enfrentaba a partidarios de Deane y de Lee, que paralizó la actividad del Congreso durante varios meses. Quizá esa inactividad debido a

129 Richard BEEMAN, Plain honest men: the making of the American Constitution, Random House, Ney York, 2009, p. 9. Según dicho autor, el Congreso era un órgano dotado de "amplias competencias, pero escasas potestades"

130 Así lo describía Sara Livingston Jay a su marido en carta fechada el 30 de diciembre de 1778.

131 "The role of the President of the Congress was limited and to some extent, unclear. His principal dity was to preside over the sesions of Congress [...] generally did not participate in debates, and Laurens once complained he was a mere silent auditor and spectator", Walter STARR, John Jay, founding father, op. cit., p. 109. 
las rivalidades politicas (con raices claramente territoriales) que tenian lugar en medio de un conflicto bélico frente a la antigua metrópoli inoculó en Jay la semilla de su pensamiento político: la opción de un poder centralizado y fuerte superador de esas divisiones que, al fin y al cabo, no tenían en el fondo otro origen que rivalidades en la que se mezclaban tanto celos profesionales como rivalidades territoriales derivadas de las ansias de preeminencia de unos lideres sobre otros.

La primera actuación de Jay al frente de su nuevo cargo tuvo su origen en la controversia que provocó su nombramiento, y en este punto hubo de enfrentarse nada menos que al británico Thomas Paine, el célebre polemista que con la ardiente defensa de la rebelión colonial americana y virulento ataque a su patria natal efectuada en su opúsculo Common Sense había inclinado no pocas simpatías del lado norteamericano. Paine, como Secretario del Comité de Asuntos Exteriores del Congreso, se había inclinado por apoyar a Lee. Al artículo que habia publicado Deane (y que, recordemos, había tenido como efecto colateral la dimisión de Henry Laurens como Presidente del Congreso Continental) Paine responde a su vez con dos escritos que aparecieron publicados en Pennsylvania Gazette, con el seudónimo fácilmente reconocible de common sense, donde atacaba ferozmente a Deane ${ }^{132}$. Ahora bien, en dichos escritos Paine comentó la imprudencia de revelar información de carácter reservado, que hacía referencia a ciertas ayudas percibidas de Francia con anterioridad a la firma del acuerdo suscrito en 1778 entre dicho reino y los Estados Unidos. Ello provocó una crisis institucional por cuanto el representante del reino de Francia, Conrad Alexander Gerard, se dirigiese por escrito al Presidente del Congreso exigiendo se adoptasen las medidas oportunas para solventar tal situación ${ }^{133}$. Jay tomó declaracion tanto a John Dunlap, director de la publicación, y a Thomas Paine, quien reconoció ser el autor de los panfletos ${ }^{134}$. El Congreso reacciona manifestando que las "insinuaciones" contenidas en las publicaciones de Paine relativas a que ciertos envíos franceses con destino a América eran "regalos de Francia" no respondian a la verdad, así como que el intento de Paine de sostener la veracidad de tan falsa afirmación remitiéndose a documentación del Comité de Asuntos Exteriores era un "abuso del cargo", por lo que se acordaba su cese inmediato en el mismo ${ }^{135}$. No obstante, Paine optó por adelantarse a su cese y presentar su renuncia al cargo que ocupaba mediante carta fechada el 8 de enero de 1779, argumentando que Deane, en su descargo público efectuado a través de la prensa, había lanzado

132 Frank MONAGHAN, John Jay, defender of liberty, op. cit., p. 112-113; Walter STARR, John Jay, founding father, op. cit., p. 113-114. Los escritos de Paine sobre el particular pueden consultarse en The writings of Thomas Paine, op. cit., vol I., p. 395-437.

133 El representante galo manifestaba que " $I$ ne doute pas que le Congrès n'ait été indifné des assertions indiscrettes que ces passages contiennent et qui compromettent egalement lui dignite et la reputation du Roi mon Maitre et cette des Etats Units. Ces assertions deviendront entre les mains des ennemis de le cause commune une arme dáutant plus puissante et plus dangereuse [...] Le Ministre susdit se repose entierement sur la prudence du Congrès pour prendre les mesures convenables á la Circonstance"; carta dirigida el día 5 de enero de 1779 por Conrad Alexandre Gerard al Congreso, en SPJJ, I, 563-564.

$$
\begin{aligned}
& 134 \text { JCC, XIII, } 30 . \\
& 135 \text { JCC; XIII, } 33
\end{aligned}
$$


una acusación al Congreso en pleno, por lo que "the honor and Justice of this House was impeached"; el polemista inglés afirma que todas sus actuaciones estuviesen presididas por la idea de "preserve the public from error and imposition, to support as far as laid in my power the Just Authority of the representatives of the People" y la circunstancia, que enfatizaba sobremanera, de que en ninguna de sus actuaciones había revelado secretos o traicionado la confianza del pueblo americano, le llevaban a dimitir, de tal manera que "as I came into office, an honest Man, I go out of it with the same Character." El iracundo Paine no quiso dejar correr el asunto y ulteriormente intentó refutar las tesis en un escrito titulado Messr. Deane, Jay and Gerard ${ }^{136}$.

En lo que respecta al asunto para el que Jay habia sido elegido, es decir, la controversia territorial con Vermont, el Presidente del Congreso Continental no se mostraba excesivamente optimista cuando en carta dirigida el 10 de enero de 1779 al gobernador Clinton indicaba que "I am not greatly deceived the Vermont Affair will end well." Las disputas internas del Congreso demoraron tan espinoso conflicto hasta el punto que en una carta que el 21 de abril de 1779 le dirigió Robert R. Livingston éste le inquiría sobre el particular advirtiéndole que algunos le responsabilizarán del retraso ("How goes the Vermont bussiness. I am fearful that you will be blamed for not procuring some settlement of it").

Es interesante la correspondencia que Jay mantiene con George Washington, comandante en jefe del ejército continental, porque en él se deslizan sutilmente muchos aspectos reveladores del pensamiento no político de Jay. Así, por ejemplo, en la carta que le remite el 3 de marzo de 1779 manifiesta de forma expresa su opción por comunicar directa y oficialmente las noticias importante a la población que esperar a que ésta tenga conocimiento de las mismas por medios oficiosos $^{137}$. Pero, sobre todo, en la carta que le dirige el 21 de abril de 1779, so pretexto de comunicarle ciertas discrepancias militares expresadas por el general Horatio Gates, revela la cercanía y el trato confidencial existente ya entre ambos personajes. Es de destacar igualmente el ya inequívoco compromiso de Jay con una causa que identificaba con la libertad, objetivo este último que deseaba no sólo para los colonos, sino para todos los individuos: "Civil and religious liberty is a blessing, which I sincerely wish to all mankind. And I hope it will be ever be the policy of these states so to extend and secure it to all their citizens, as that none may have reason to complain of partiality and oppresion"138.

Una de las cuestiones que ocupó y preocupó a Jay durante este corto e intenso periodo fue sin duda alguna las negociaciones para intentar atraer a España a una alianza con los nuevos Estados Unidos, por lo que hubo de tratar frecuentemente con Gerard, representante de Francia, y con el enviado oficioso de la corona española, Juan de Miralles. Jay estaba perfectamente al tanto de los Pactos de Familia que ligaban a las coronas francesa y española, y buena prueba

136 Puede consultarse en The writings of Thomas Paine, I, 438-445.

137 "The opinion that greater advantages result from communicating important events to the people in an authentic manner, tan by unauthorized reports, is certainly just, tho often neglected", SPJJ, I, 601 .

138 Carta a Anthony Bezenet, 5 de marzo de 1779, SPJJ I, 604 
de ello es que en carta dirigida el 2 de marzo de 1779 a George Washington le trasladaba el tratado entre ambas potencias continentales europeas con la siguiente adenda: "is a Copy of the Family Compact between the Branches of the House of Bourbon. As it explains the political Connection between France and Spain, I think it is interesting." Los Estados Unidos trataban, pues, de que España se implicase de forma oficial, mediante una declaración expresa de Guerra frente a Gran Bretaña seguida de un reconocimiento explícito a los Estados Unidos. No obstante, la posición de España en cuanto a su relación con las colonias rebeldes fue ciertamente peculiar y estaba de alguna manera condicionada por su presencia física en el continente americano, circunstancia ésta que impulsó a los dirigentes españoles a conducirse con suma prudencia y no dejandose guiar por simples filias o fobias; no deja de ser en este punto curiosa la manera con que Frank Monaghan se refiere a los dirigentes españoles del momento: "Spanish statemen then possessed an unusual degree of perspicacy"139. Lo cierto es que desde el primer momento se decidió ofrecer ayuda a las colonias, pero sin involucrarse expresamente, tanto por el legítimo temor a que el ejemplo se contagiase a los territorios que España poseía en el continente americano como por el hecho de que unos Estados Unidos independientes pasarian a ser unos incómodos vecinos de la Corona española, al lindar el territorio estadounidense con el español tanto por el sur (Florida) como por el oeste (Luisiana, territorio que los franceses habian cedido a España en 1763). No obstante, en junio de 1779 España declara formalmente la guerra a Gran Bretaña, entrando así de forma expresa en el conflicto bélico. Y fue precisamente ese hecho, la entrada oficial de España en la guerra de independencia norteamericana, la que vino a condicionar la vida de John Jay durante los próximos cinco años, pues los días finales del mes de septiembre de ese año de 1779 Jay es elegido como ministro plenipotenciario para negociar un tratado con España.

Con todo, dias antes de renunciar a su cargo en el Congreso Continental para asumir sus nuevos deberes como representante diplomático en España, a Jay se le presenta la ocasión para dejar explícito su pensamiento acerca de la situación política interna e intenacional. El día 3 de septiembre de 1779 el Congreso aprueba la creación de un comité de cinco personas encargado del estudio e informe de las medidas tendentes a vigorizar las finanzas de la Confederación así como para elaborar una circular a los distintos estados, siendo las cinco personas elegidas para ello Henry Laurens, Elbridge Gerry, Samuel Huntington, John Dickinson y Meriwether Smith. Cinco dias más tarde, a propuesta de Henry Marchant, se acuerda que fuese el Presidente del Congreso Continental quien elaborase una circular a los distintos estados para que cesasen en la emisión de papel moneda ${ }^{140}$. El 13 de septiembre de 1779 Jay somete al

139 Frank MONAGHAN, John Jay, defender of liberty, op. cit., p. 119. Para examinar el papel de España en relación con la independencia norteamericana, existen dos estudios de título muy similar. El primero, es el ya clásico debido a J. YELA UTRILLA, España ante la independencia de los Estados Unidos; el segundo, mucho más reciente, es el de Thomas CHAVEZ, España y la independencia de los Estados Unidos, Taurus, Madrid, 2006.

140 JCC, XV, 1019-1020 y 1036. La expresión popular “not worth a continental”, referida precisamente al nulo valor de la moneda, viene precisamente del escaso valor del papel moneda emitido durante la guerra de independencia norteamericana. 
Congreso su Circular letter from Congress to their Constituents ${ }^{141}$, que es aprobado por unanimidad. Dicho escrito no sólo demuestra una lúcida exposición de problemas de naturaleza financiera ${ }^{142}$, sino que revela ya una evolución en el pensamiento político de Jay no sólo en cuanto a la irreversibilidad del movimiento independentista, sino por estar inspirada en una visión "nacionalista" que considera los Estados Unidos como una simple unión de estados.

Es significativo que Jay inicie su escrito exponiendo el rol de los gobernantes en un sistema basado en el principio natural de libertad, en el cual "the rulers of the state are the servants of the peopoe, and not the masters of those from whom they derive authority". Y una de las principales obligaciones de los gobernantes es informar a los ciudadanos del estado de los asuntos públicos. La emisión de papel moneda vino provocada por la necesidad de obtener fondos para sostener la guerra frente a la metrópoli, conflicto inevitable debido al "unnatural designs of the British king and his venal parliament to enslave the people of America, reduced you to the necessity of either asserting your rights by arms, or ingloriously passing under the yoke. You nobly prefer war." En el escrito se impute la situación al Rey y al Parlamento, descritos con los más negros tintes, pero se descarga explícitamente de toda responsabilidad al pueblo inglés, de quien se manifiesta que fue "sold to and betrayed by their own representatives" Hasta este momento, Jay no hace más que recoger la tesis que ha mantenido incólume durante todo ese tiempo, es decir, que el conflicto se debe al intento del monarca y el parlamento inglés de esclavizar a las colonias. Pero a continuación da un paso más y defiende una tesis que supera sus convicciones anteriores: una posible solución amistosa al conflicto que restablezca los lazos con la metrópoli es ya inviable, por lo que la independencia de las colonias ha pasado a ser ya un hecho irreversible ${ }^{143}$. Tras reconocer que Gran Bretaña sufre una situación de aislamiento internacional y que sostiene la guerra contra sus antiguos colonos sin apoyo alguno, enuncia la que es la tesis central y decisiva: los Estados Unidos no son una entidad coyuntural limitada en el tiempo hasta el final del conflicto, sino que se trata de una entidad permanente debida a la unión o hermandad cultural, linguística y de intereses, llegando a decir en una hábil metáfora que tanto la "hermandad en el dolor" como los lazos comunes han forjado "una cadena que nos unirá para siempre"144. Los intentos de sembrar las dudas en cuanto a

$141 \mathrm{JCC}, \mathrm{XV}, 1052$.

142 Frank MONAGHAN, John Jay, defender of Liberty, op. cit., p.

143 "That the time has been when honest men might, without being chargeable with timidity, have doubted the sucess of the present revolution we admit; but that period is pased. The Independence of America is now as fixed as gate, and the petulant efforts of Britain to break it down are as vain and fruitless as the raging of the waves which beat against her cliffs"

144 "But we are persuadded, and our enemies will find that our Union is not to end here. They are mistaken when they suppose us kept together only by a sense of present danger. It is a fact which they only will dispute, that the people of these States were never so cordially united as at this day. By having been oblged to mix with each other, former prejudices have worn off, and their several manners become blended. A sense of permanent interest, mutual affection (habing been brethren in affliction), the ties of cosanguinity daily extending, constant reciprocity of good offices, similarity in language, ingovernments, and therefore in manners, the importance, weight and splendour of the Union, all conspire in forming a strong chain of connection, which must for ever bind us together." 
ello no son más que una mera treta de los enemigos para sembrar la discordia y la desconfianza en el crédito público.

Jay abandona, pues, no sólo la Presidencia del Congreso Continental, sino el propio territorio estadounidense con una apelación a la comunidad de intereses entre los estados y a una visión de la unidad nacional como algo que trasciende a los propios entes estatales y que se perpetuará más allá del conflicto belico. Se trata, pues, de una interpretación ya abiertamente "nacionalista" que los años no harán más que profundizar y acentuar.

\subsection{Nombramiento como ministro plenipotenciario de los Estados Unidos en España.}

Casi finalizado el mes de septiembre de 1779 se produciría un acontecimiento que marcaría una cesura en la vida personal y profesional de Jay: su elección como ministro plenipotenciario para negociar un tratado con España. En efecto, el día 27 de septiembre de 1779. El Congreso Continental acuerda "proceed to the election o a minister plenipotentiary to negotiate a treaty of alliance and of amiti and commerce between the United States of America and his Catholic Majesty", cargo para el que es elegido Jay. Ese mismo dia, el Congreso nombra a otro destacado patriota americano, John Adams, como "minister plenipotentiary for negotiating a treaty of peace and a treaty of commerce with Great Britain."145

\section{EPÍLOGO. CIERRE DE UNA FRUCTÍFERA ETAPA.}

Con su salida del territorio norteamericano para incorporarse a su nuevo cargo de embajador en España, Jay ponía fin a seis años de intensa dedicación a la politica tanto estatal como supraestatal. De ser un brillante abogado en una colonia británica, pasó a ser una brillante figura política en el Congreso Continental y una pieza indispensable en la articulación y puesta en marcha del estado de Nueva York. Y si bien en el ocaso del año 1779 finalizaba una etapa dedicada principalmente a la politica interior, comenzaria otra que se prolongaria durante cinco años en los cuales la diplomacia le ocuparía de forma casi exclusiva, tarea en la cual destacaría sobremanera hasta el punto que, cuando regresó finalmente en junio de 1784 a unos Estados Unidos ya reconocidos por su antigua metrópoli como estados independientes, lo haría por la puerta grande, al pisar terreno norteamericano no como simple particular, sino como flamante Secretario de Asuntos Exteriores de los Estados Unidos de América, es decir, como responsable máximo de la diplomacia confederal. La evolución política de los Estados Unidos bajo los Artículos de la Confederación y la propia experiencia de Jay como Secretario de Asuntos Exteriores le hicieron profundizar en la necesidad de una reforma institucional que diese el paso hacia una auténtica federación, con un poder central fuerte que se sobrepusiese a los estados, cuyas competencias debían ser reducidas al mínimo indispensable.

Pero esa etapa de Jay como máximo representante de la diplomacia estadounidense y como teórico del federalismo ya es otra historia.

145 JCC, XV, 1113. 